\title{
Complexity, Leadership, and Megaproject Performance: A Configuration Analysis
}

\author{
Retno Damayanti (D), Budi Hartono iD, Andi Wijaya \\ Industrial Engineering Program, Mechanical and Industrial Engineering Department, \\ Universitas Gadjab Mada (Indonesia) \\ retno.wulan.d@mail.ugm.ac.id, boed@gadjahmada.edu, andi.wïaya@ugm.ac.id
}

Received: January 2021

Accepted: May 2021

\begin{abstract}
:
Purpose: Rapid worldwide growth in megaprojects has attracted academic interest. In practice, complexity is one of the main causes for the failure of megaprojects. This study proposes a system of project manager leadership to overcome problems of complexity in achieving success with a megaproject.

Design/methodology/approach: This study uses configuration analysis, furzy-set qualitative comparative analysis (fsQCA), to investigate the combination of complexity and leadership competencies that promote megaproject success. This study analyzes three megaproject manager leadership competencies-technical, emotional-social, and adaptive-with three megaproject complexities-structural, social, and emergent-to determine the combinations and levels required to ensure a megaproject's short- and long-term success. Seven Indonesian infrastructure megaprojects were involved in this explorative study.

Findings: This study has identified four combinations between complexity and leadership competencies and three necessary conditions that can lead to a successful megaproject. This study also reports that insufficient project manager leadership competence in the technical, emotional-social, and adaptive aspects can lead to lower megaproject performance.

Research limitations/implications: By using fsQCA, this study is sufficient to understand the combination of complexity and leadership competencies in the megaproject performance. However, configuration comparative analysis using small samples is unable to explain the results that are more rigorous compared with the statistical approach. Having higher cases and additional analytical approaches leading to a more robust quantitative analysis method is needed to address these limitations.

Practical implications: For practitioners, this study proposes effective leadership competency combinations for managing various complexities of the megaproject.

Originality/value: This study provides an insight into the competencies of megaproject management leadership. It contributes to the literature by providing fresh perspectives on megaproject management, especially in terms of complexity and leadership. This is an important research area for the development of megaproject management theory filling theoretical gaps in megaproject management in terms of the leadership aspect.
\end{abstract}

Keywords: complexity, configuration analysis, leadership, megaproject performance 


\section{To cite this article:}

Damayanti, R., Hartono, B., \& Wijaya, A. (2021). Complexity, leadership, and megaproject performance: A configuration analysis. Journal of Industrial Engineering and Management, 14(3), 570-603.

https://doi.org/10.3926/jiem.3476

\section{Introduction}

Population growth, technological advancements, business developments, and shifts in human needs have led to the development of large-scale infrastructure projects termed "megaprojects" (Flyvbjerg, 2014), "big projects" (Ahola, 2012), "giant projects" (Grün, 2004), "large projects" and "major programs" (Hu, Chan, Le \& Jin, 2015). Since the late 1990s, megaprojects have grown globally not only in developed countries such as Britain and France but also in developing countries like China, India, and Indonesia (Damayanti, Hartono \& Wijaya, 2019).

Characteristically, these types of projects are defined as having high-cost investments of more than $\$ 1$ billion (Flyvbjerg, 2014) or an average of $0.01 \%$ of the country's gross domestic product (GDP) (Hu, Chan \& Le, 2015; Zhou \& Mi, 2017). The physical aspects (e.g., size, design, and scope) of the projects are beyond ordinary, having the longest, highest, and biggest construction, which become a megaproject's features (Flyvbjerg, 2014). Because of budget and construction size, megaprojects need the involvement of multi-entities (e.g., teams or organizations), shareholders, and stakeholders (Li, Lu, Taylor \& Han, 2017). These entities come from various backgrounds, such as multiple cultures and countries (Gerhard \& Christian, 2008; van Marrewijk, Clegg, Pitsis \& Veenswijk, 2008) involving different motives that may trigger conflicts (Li et al., 2017; Ruuska, Artto, Aaltonen \& Lehtonen, 2009). Megaprojects are developed over several years (Brockmann, 2009; Zidane, Johansen \& Ekambaram, 2013), which increases uncertainty because of dynamic global business (Kardes, Ozturk, Cavusgil \& Cavusgil, 2013), laws and regulations (Rad, Sun \& Bosché, 2017), and changes in stakeholder political interests (Qiu, Chen, Sheng \& Cheng, 2019).

Environment ecological issues (Ma, Zeng, Lin, Chen \& Shi 2017; Zeng, Ma, Lin, Zeng \& Tam, 2015), geographical locations and uncertain natural conditions (Bosch-Rekveldt, Jongkind, Mooi, Bakker \& Verbraeck, 2011; Lessard, Sakhrani \& Miller, 2014), and novel technology system innovations (Ahn, Shokri, Lee, Haas \& Haas, 2017) add to the challenges of megaprojects. From this description, it is clear that megaprojects have much more complex social, cultural, institutional, and technical aspects than ordinary projects (Li, Han, Luo \& Zhang, 2019).

Indeed, megaprojects come hand in hand with mega-problems (Flyvbjerg, 2013), which may lead most megaprojects to failure (Flyvbjerg, 2014; Ninan, Clegg, Burdon \& Clay, 2021). However, if successful, a megaproject can make a region prosperous and even become a unifying symbol for the country (Flyvbjerg, 2013). Therefore, it takes rigorous effort, more than in ordinary projects, along with a proper approach to manage a megaproject (Flyvbjerg, 2014; Li, Han et al., 2019; Locatelli, Mikic, Kovacevic, Brookes \& Ivanisevic 2017).

From a complexity perspective, one can effectively understand and manage a megaproject (Flyvbjerg, Bruzelius \& Rothengatter, 2003; Sato \& Chagas Jr, 2014). This perspective can serve as a powerful analytical lens in terms of observing intricate problems that may stem from various project management settings, such as project failure (Ivory \& Alderman, 2005), knowledge management (Hartono, Sulistyo, Chai \& Indarti, 2019), stakeholders (Aaltonen \& Kujala, 2016), leadership (Hartono, Sulistyo \& Umam, 2019), tasks and scheduling (Ahn et al., 2017), team (Hsu, Weng, Cui \& Rand, 2016), and project practice (Cooke-Davies, 2011). However, the literature review exhibits a limited focus in the context of megaproject studies.

Thus, this study redefines megaproject management from a complexity perspective. While few complexity studies have focused on regular project management, the findings are not often applicable in the context of a megaproject. Megaprojects differ in that in megaprojects there are significantly more problems to resolve and greater complications to address, that is, they operate at a higher level of complexity (Li, Han et al., 2019; Müller, 2014). Therefore, this study posits that a traditional plan-and-control project management approach is insufficient for addressing the multifaceted problems in megaprojects (Shenhar, 2004). 
Furthermore, from a temporary organizational perspective, project management entails managing both technical aspects and leadership (He, Luo, Hu \& Chan, 2015; Graham, Nikolova \& Sankaran, 2020; Pitsis, Clegg, Freeder, Sankaran \& Burdon, 2018). Megaprojects often transcend technical activities and task relationships as they involve significant human relationships that include both internal and external stakeholders (Amoatey \& Hayibor, 2017; Denicol, Davies, \& Pryke, 2021). Consequently, it has been deemed crucial to look into leadership aspects in megaproject management.

Previous studies on regular project management have suggested that effective leadership depends on the project setting or attributes (e.g., the type of project (Müller \& Turner, 2007), industry type, and project complexity (Hartono, Sulistyo \& Umam, 2019). Similar strategies potentially apply in megaprojects, wherein project managers make choices according to the megaproject and its complexities (Sankaran, 2018). Therefore, to deal with possible megaproject complexities, project managers must have strong leadership competencies (Li, Lu, Cui \& Han, 2019). As megaprojects are expected to have far greater challenges than conventional projects, project manager leadership competencies are presumed to be better (Flyvbjerg, 2014; Li, Lu et al., 2019). Nevertheless, there is limited research on project managers' leadership competencies in megaprojects (Li, Lu et al., 2019), especially in managing complexities. Therefore, this study aims to explore project managers' leadership competencies in terms of managing complexities for a successful megaproject.

This study examines leadership competencies in response to complexity in the form of a combination configuration approach. The proper configuration combining certain "leadership competency" and "complexity" has been determined to play a key role in achieving a successful megaproject. This exploratory study adopts the fuzzy-set qualitative comparative analysis (fsQCA), a method with a comparative approach that balances qualitative exploration through case studies as well as combination variables configurational that analysis quantitatively based on the Boolean algebra (Rihoux \& Ragin, 2009).

This study offers both theoretical and practical contributions as it extends the existing literature by proposing a megaproject management approach that simultaneously analyzes the "complexity" and "leadership" involving a megaproject. This study also introduces a relatively new method in engineering management that is comparative analysis fsQCA for empirical examination and analytical in a configurational. With regard to its practical contributions, this study proposes combinations solution of leadership competencies in varying contexts of megaproject complexity to support project managers manage the megaprojects achieving the success target.

This study is presented in five sections. Section 1 elucidates the background and the problem formulated in the research objective. Section 2 provides a literature review concerning complexities in megaprojects as well as the management approach and megaproject leadership. Section 3 presents the research methods, detailing the study approach and procedures. Section 4 explains the discussion and research findings as well as the research contribution to engineering management. Section 5 contains the conclusion and limitations as well as suggestions for further research.

\section{Literature Review}

\subsection{Complexity and Megaproject}

Looking into megaproject complexity, researchers have identified complexity as a critical factor for success. Some researchers concluded that several megaprojects failed due to a lack of understanding and required methods to address the complexities associated with megaprojects (Shenhar \& Holzmann, 2017).

Despite megaproject complexities becoming one of the primary reasons for a megaproject to fail, studies on this topic are scarce. Between 2000 and 2010, several prominent project and engineering management journals included only $4.7 \%$ of 85 studies examining megaproject complexities (Hu, Chan, Le \& Jin, 2015). This result is consistent with a study conducted by Wang, Chan, He, and Xu (2020), who noted a gap in megaproject studies conducted between 2007 and 2018, identifying that only $7.2 \%$ of 145 studies focused on complexity management.

Most previous research attempted to explore the complexities and management of megaprojects. Some researchers have discussed the topic and related it to the size or several interrelated structural aspects; for instance, the interrelatedness of many goals (Rad et al., 2017; Bosch-Rekveldt et al., 2011), the number and diversity of tasks and activities (Gerhard \& Christian, 2008; Rolstadås \& Schiefloe, 2017), high technology integration (Lu et al., 2015; 
Ahn et al., 2017), law and regulation (He et al., 2015; Othman, 2013), the project budget (Kardes et al, 2013; Chapman, 2016), and many other resources and organizational structures (Rad et al., 2017; Lu, Luo, Wang, Le \& Shi, 2015). Borrowing from project complexity, this aspect of complexity should be classified as a dimension of structural complexity (Maylor, Turner \& Murray-Webster, 2013; Maylor \& Turner, 2017).

As a megaproject requires involvement from many teams and stakeholders, past researchers have also highlighted the complexity of social human aspects concerning cultural backgrounds or political motives (e.g. Jia, Yang, Wang, Hong, \& You, 2011; van Marrewijk et al., 2008). Having a transnational team is often common in megaprojects. Because of differences in organizational and national cultures, this can a challenge for team collaboration; examples include, dealing with different team cultures in a large project partnership in Thailand (Prasitsom \& Likhitruangsilp, 2015a), in an energy megaproject in Siberia (van den Ende \& van Marrewijk, 2015), and an oil and gas megaproject in Vietnam (Van Ban \& Hadikusumo, 2017). Additionally, most stakeholders often have different motives and interests, which has emerged as a complexity concern in a megaproject. For example, the challenge discussed by Wu, Jia and Zhang (2019) has been evident for the infrastructure trunk line between the Beijing and Shenyang megaproject in China, the Mashhad Urban Railway project in Iran (Bahadorestani, Karlsen \& Farimani, 2020), the partnership alliance contract between the client and contractor in Main Roads Western Australia (Galvin, Tywoniak, \& Sutherland, 2021), and in some large projects around the world as examined by Di Maddaloni and Davis (2017). In this study, these aspects were categorized as social complexity, in line with the term from the context of social dimension project complexity (Maylor \& Turner, 2017).

Some researchers have also highlighted changes and uncertainties that megaprojects may encounter. Brady and Davies (2014) analyzed complexity from a dynamic matter in Heathrow terminal 5 and the 2012 Olympic park in London, United Kingdom. Giezen (2013), on the other hand, discussed the uncertainty challenges in a large infrastructure project in the Netherlands, whereas Nätti (2016) studied the strategic network under an uncertainty power plant megaproject in Finland. Some researchers in developing countries have noted that new advancements in technology, lacking knowledge in organizing a megaproject, and unstable political and economic conditions can increase uncertainty in a megaproject (e.g., Babatunde, Perera, Udeaja \& Zhou, 2014; Brahm \& Tarziján, 2015). These dynamic aspects relate to the change and uncertainty factors and are often referred to as emergent complexity (Geraldi, Maylor \& William 2011; Maylor \& Turner, 2017); this term has also been adopted as a complexity dimension in this study.

Thus, in analyzing a megaproject's complexity, this study considered three aspects as dimensions of complexity: (1) structural complexity, which refers to scale and interrelationship; (2) social complexity, which refers to human factors, such as teams and stakeholders, with varying cultural and political backgrounds; and (3) emergent complexity, which refers to changes and uncertainties that a project may face.

\subsection{Megaproject Complexity Management}

In a study by Maylor and Turner (2017), three approaches were proposed to address a project's complexity: standard project management based on planning and control to respond to structural complexity; social engagement, consisting of the management of teams and stakeholders to address social complexity; and change with adaptive management to handle emergent complexity.

However, in megaprojects, approaches to complexity management must be expanded because multiple aspects can be highly interrelated, megaprojects have wider scopes as compared to an ordinary project, and larger entities are involved. Based on existing literature, a standard complexity management approach is still utilized in megaprojects; however, it must go hand in hand with a contemporary approach. For instance, robust integration management (Brady \& Davies, 2014; Chen, Su, Zeng, Sun \& Shi, 2018) along with standard project management, which is focused on planning and control (Maylor \& Turner, 2017) are considered in response to the structural complexity involved with a megaproject.

Social engagement, which emphasizes emotional management strengthened by a creative humanist approach, has been used to address social complexity in a megaproject; this is in addition to the standard project teams and stakeholders' management (Gerhard \& Christian, 2008; Wang, Han, de Vries \& Zuo, 2016). Aside from change management and other adaptive, dynamic, creative, and flexible approaches (Li, Han et al., 2019), innovation 
management is highly recommended for addressing the emergent complexity in a megaproject (Chapman, 2016; Chen et al., 2018).

\subsection{Leadership and Megaproject}

For most researchers, leadership is identified as a key aspect to achieving the short-and-long-term success of a megaproject (Li, Lu et al., 2019; Denicol, Davies \& Krystallis, 2020). To date, researchers are still exploring the leadership competency that a project manager requires to manage a megaproject.

Considering the size and several interrelated factors, when dealing with megaprojects, project managers should have high technical competency and possess the following skills: procedural planning and control (Callahan, Pisano \& Linder, 2010; Wu, Fang \& Li, 2015; Sankaran, 2018); alignment and integration (Mazur \& Pisarski, 2015); knowledge and experience to exploit current and available resources (van Johnston, 2011; Sankaran, 2018). As a megaproject can also involve several social entities, project leaders must have social competency (Parent, Olver \& Séguin, 2009; Sankaran, 2018). This point was discussed by Mazur, Pisarski, Chang and Ashkanasy (2014) after studying a defense industry megaproject in Australia, wherein project managers exhibited high emotional-social competency when managing their stakeholders. Additionally, social competency allows proper communication, negotiation, and collaboration among multi-party teams (Wan, Le, Wang, Xia, \& Liu, 2020) and stakeholders (Toor \& Arain, 2012; Raziq, Borini, Malik, Ahmad \& Shabaz, 2018; Sankaran, 2018).

On the other hand, a project leader should also be flexible and adaptive, which are traits necessary to overcome change and any uncertain conditions that a megaproject might face. For instance, Callahan et al. (2010) discussed how the Alameda Corridor and Alameda Corridor East megaproject managers in the USA were able to cope with uncertainties by employing flexible leadership strategies through stakeholder lobbying. Based on a narrative inquiry approach, Sankaran (2018) pointed out that megaproject managers must adapt to the project milieu to establish their individual roles, as it is important to balance all aspects of the project to support innovation and to meet unanticipated requirements. Recently, Wan et al. (2020) discussed top managers in megaprojects across China, with a focus on adaptability in the paternalistic styles of leadership.

Although leadership has a clear effect on the success of a megaproject, previous research provides little insight regarding what and how leadership competencies fit into the context of megaproject complexity. From the complexity management approach and based on past megaproject leadership studies, three leadership competencies for megaproject managers are potentially proposed: (1) technical competency, which emphasizes one's ability to integrate consideration for the existence of multiple factors (e.g., activities, costs, organization, and technology); (2) emotional-social competency or social engagement management ability, which requires emotional intelligence with a creative human approach as megaprojects often involve multiple entities and possibly multiple countries with different backgrounds and motives (i.e., teams and stakeholders); and (3) adaptive competency, which emphasizes one's ability to change and shift while simultaneously balancing all factors, requiring an innovative mindset.

\section{Methodology}

\subsection{Research Approach}

This study aims to explore leadership competency in terms of managing complexities for a successful megaproject. This study is multivariable and involved three research factors (i.e., complexity, leadership competency, and megaproject performance) as main variables; each variable was divided into sub-variables for further analysis (Hair Jr., Black, Babin \& Anderson, 2014; Neuman, 2007). Although these research variables seem interrelated, previous studies have not established how leadership competency and complexity affect the performance of a megaproject.

For an in-depth analysis, this study uses the conjunctural causation approach, which examines the cause and effect between variables not only in a single relationship but in a causal combination (Rihoux \& Ragin, 2009). The fuzzy-set qualitative comparative analysis (fsQCA) from QCA method was identified as suitable for this study, as it is based on a comparison approach that balances the qualitative analysis of case studies with quantitative multivariable relationship analysis using Boolean algebraic calculations (Ragin, 2014; Rihoux \& Ragin, 2009); thus, it is suited for research where interactions between variables are not well understood (Jordan, Gross, Javernick-Will, \& Garvin, 2011). 
The fsQCA approach uses specific terms to define the research variables and their relationships, namely, "outcome" to define the dependent variable and "causal condition" for the independent variable (Ragin, 2014). The relationship of the principal variables is referred to as the explicit connection. From the regression/correlation perspective, the relationship is simultaneous, symmetrical, and equivalent at the level of the existence of variables. However, from the explicit connection perspective, this analysis focuses on both the symmetry and asymmetry of the variable relationship (Ragin, 2008). Rather than examining the value or the strength of the relationship between condition variables on the outcome/result, the configurational form or the combination of variables is analyzed.

Following the given objectives, the "outcome" of this study is megaproject performance, namely, the short-term success targets (e.g., the iron triangle of time, cost, and quality) (Flyvbjerg, 2014) and long-term targets (e.g., client or customer satisfaction, team satisfaction, and community benefits) (Bahadorestani et al., 2020; Sato \& Chagas Jr., 2014). These outcomes are analyzed in both high and low performance.

\subsection{Research Procedure}

In this study, the research procedure was adapted from the fsQCA stages by Berg-Schlosser and De Meur (2009) and Mendel and Korjani (2013). The procedure began with a formulation of the outcome, followed by the case selection, the formulation of causal conditions, the research model development, and the data collection stage. The next stage is data processing, ending with an interpretation of the result. A summary of these stages is presented in: Figure 1. Flowchart of the fsQCA study.

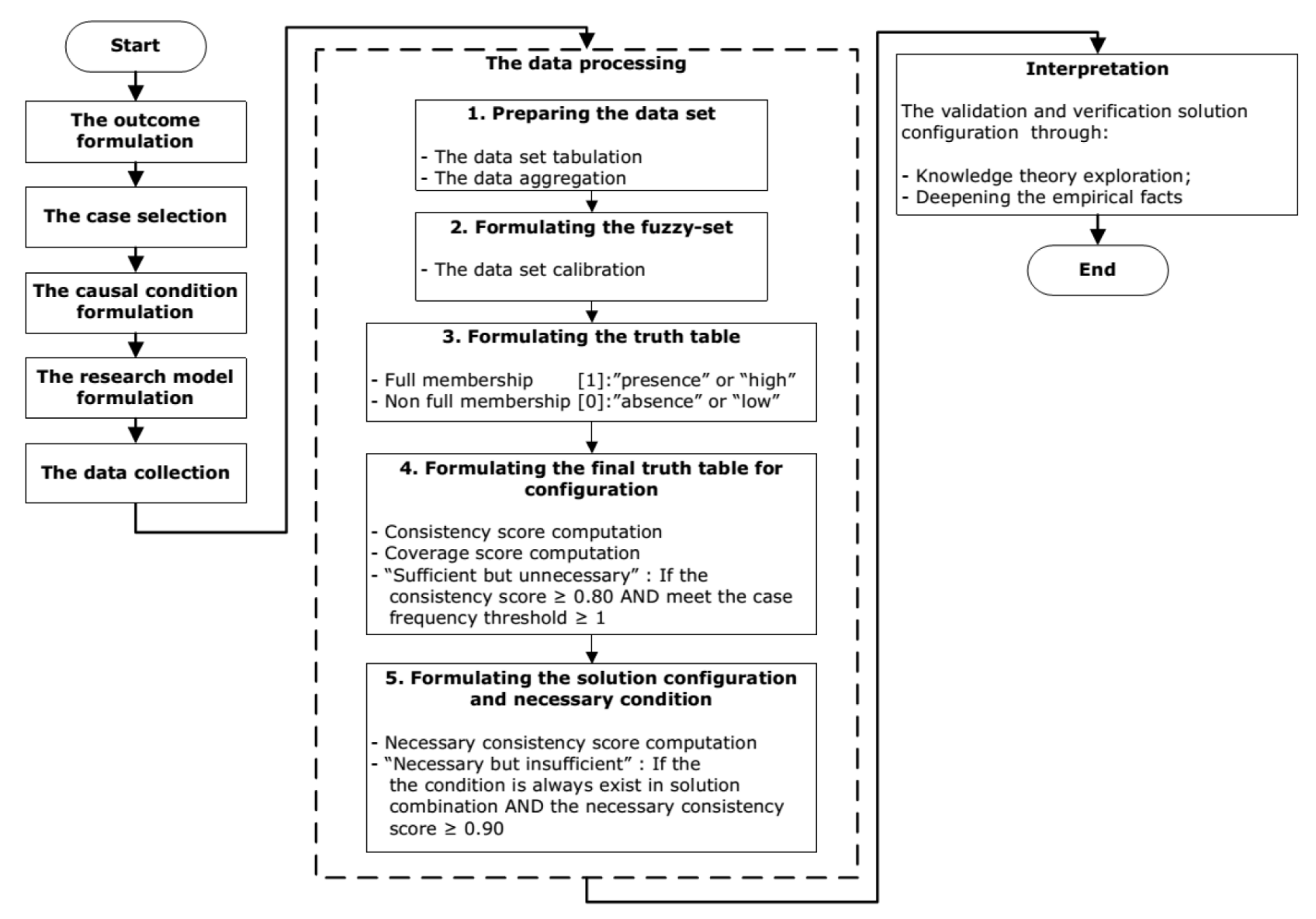

Figure 1. Flowchart of the fsQCA study

\subsubsection{The Outcome's Formulation}

The "outcomes" formulation of this study is explained in sub-chapter 3.1, namely the short-term and long-term megaproject targets, which are studied in high and low performance. 


\subsubsection{The Case Selection}

After the "outcome" of a study is determined, to establish the boundaries on which cases are selected, the investigation domain must be defined (Berg-Schlosser \& De Meur, 2009). The cases analyzed for comparison were selected based on clear and specific considerations.

The strategy considered in case selection for this study was the most similar system design, termed "Most Similar Different Outcome." This strategy is based on the concept of exploring cases with similar system characteristics that may have conflicting outcomes (Berg-Schlosser \& De Meur, 2009). The boundaries set on this study are as follows: (1) The case selection was based on megaproject cost, which involved a minimum spending of $0.01 \%$ of a country's GDP (Hu, Chan \& Le, 2015; Zhou \& Mi, 2017) or equaled a minimum project budget of USD 87 million for an Indonesian setting. (2) The cases were Indonesian megaprojects on transportation, which has been identified as a national priority infrastructure project until the year 2025 (Committee for Acceleration of Priority Infrastructure Delivery, 2018). (3) To obtain a full description of the project, the selected megaproject cases must be completed in the year 2019 .

Based on these criteria, seven megaprojects in Indonesia were selected for analysis: two Indonesia Light Rail Transit systems (i.e., ILRT-Jt and ILRT-P), three toll roads along the Trans-Island Highway (i.e., Trans-J, Trans-S, and Trans-L), one Indonesia City Mass Transit (ICMT), and one International Indonesia Airport (IIA). The chosen megaprojects were part of Indonesia's national priority infrastructure, a strategic initiative sponsored by the Indonesian Government in its effort to transform the nation into a developed country by 2045 (Committee for Acceleration of Priority Infrastructure Delivery, 2018). These seven cases were largely sufficient to conduct this study, as they represented the typical Indonesian transportation infrastructure for megaproject construction.

The average investment value of these megaprojects was around USD 1.054 billion. The actual construction duration for these megaprojects was estimated to be 24-72 months. Several projects were completed in 2018 and mid-2019 (i.e., IIA, Trans-J, ICMT, and ILRT-P), while nearly $60 \%$ were delayed by 12 months (Appendix A).

\subsubsection{The Causal Condition}

The selection of conditions must be based on theoretical or literary criteria and should match the observed cases (Berg-Schlosser \& De Meur, 2009). In this study, we examined the performance of megaprojects to identify relevant combinations of leadership competencies and complexity. With this in mind, six causal conditions, three conditions of complexity (i.e., structural, social, and emergent), and three leadership competencies (i.e., technical, emotional-social, and adaptive) were simultaneously analyzed to characterize and assess megaproject performance (i.e., short- and long-term).

\subsubsection{The Research Model}

To analyze the explicit connection, the fsQCA uses the conjunctural causation approach, which examines the cause and effect between variables not only in a single relationship but in causal combination (Rihoux \& Ragin, 2009). Figure 2 shows the conceptual model for this study. When verified, the connection model is explained as "The combination of conditions that are relevant for assessing the performance of megaproject is: structural, social, emergent complexity, technical leadership competence, emotional-social, and adaptive."

The hypotheses in fsQCA are assumed, in which all conditions and outcomes are proposed in combination (Berg-Schlosser \& De Meur, 2009). Therefore, the conjunctural hypothesis in this study is stated as "The combined complexities and leadership competencies result in certain megaproject performances." 


\section{Complexity}

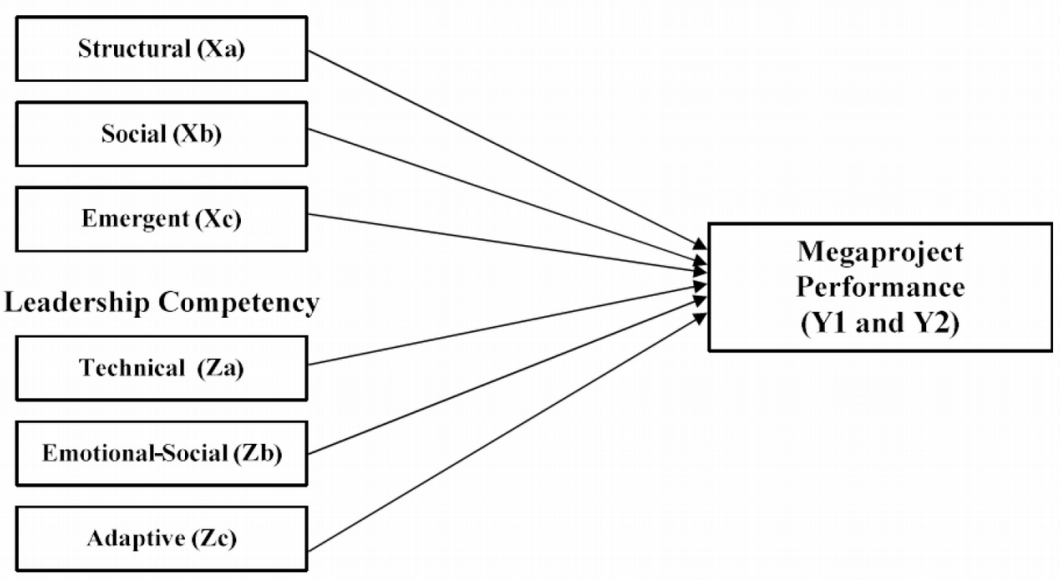

Figure 2. Theoretical Model

\subsubsection{Data Collection}

Data collection comprised the respondent selection and the data collection method, which will be explained further as follows.

\subsubsection{Respondent Selection}

This study focuses on the leadership competencies of the top (chief) megaproject manager. Seven top megaproject managers were chosen as respondents. These respondents were ultimately responsible for the success or failure of their respective megaprojects and those that best-comprehended complexity. As per our findings, most of our respondents shared that it is their first time handling a megaproject as top managers, whereas three of the seven had prior experience in managing megaprojects as chief engineers and technical managers. All of them were certified engineering, procurement, and construction experts and had more than 15 years of experience in an infrastructure construction project.

\subsubsection{Data Collection Method}

Three data collection methods were used: questionnaire, interview, and document exploration. To formulate questionnaires, this study adopted several statements from literature (e.g., the complexity assessment tools by Maylor et al. (2013)) and from the leadership dimension questionnaire by Dulewicz and Higgs (2005).

This study used a two-way translation mechanism to prevent misunderstandings as the original variables and sub-variables from the literature were in English and the respondents used Indonesian. It took at least two individuals who understand the two languages to do the translation process. The translation process has been based on the method introduced by Brislin (1970), with operational stages based on Marín and Marín (1991). The results of the two-way translation were then compiled into a draft questionnaire.

The pilot study was conducted to assess the questionnaire's validity and reliability. For exploratory studies, a reliability value of at least 0.6 was acceptable (Bagozzi \& Yi, 1988). The operational definition of the variable and the final attributes for the questionnaire are shown in Table 1. The detailed attributes from a completed questionnaire are presented in Appendix B.

The final questionnaire (shown in Appendix B) was distributed to the respondents through an online SurveyMonkey web survey. A 7-point Likert scale was used to capture the answers from respondents (1, strongly disagree; 2 and 3, between strongly disagree and neutral; 4, neutral; 5 and 6, between neutral and strongly agree; 7, strongly agree). This scale has been identified to provide accurate measures related to respondent perceptions when the respondents' entries are unsupervised (Finstad, 2010). The weight of this scale value was assumed to be uniform. Using the summated scale method (Hair Jr. et al., 2014), aggregate scores were obtained by summing and calculating the average Likert response value for each variable. 
This exploratory case study included an interview to obtain further explanation on the condition of the observed megaproject; this will also serve as a validation and verification process for this study. The respondents (seven top managers of megaproject) were followed up as interviewees. Interviews were conducted with each respondent, which lasted for 1-2 hours. Three were face-to-face interviews, three through conversation chats in social media applications, and one through an online video call.

\begin{tabular}{|c|c|c|c|c|c|c|}
\hline Variable & Definition & $\begin{array}{l}\text { Causal } \\
\text { Condition }\end{array}$ & $\begin{array}{l}\text { Operational } \\
\text { Definition }\end{array}$ & Attributes & References & $\begin{array}{l}\text { The } \\
\text { Cronbach } \\
\text { Score }\end{array}$ \\
\hline \multirow{3}{*}{$\begin{array}{l}\text { Complexity } \\
\text { (X) }\end{array}$} & $\begin{array}{l}\text { Positive and } \\
\text { negative } \\
\text { challenges that } \\
\text { must be } \\
\text { addressed by } \\
\text { megaproject } \\
\text { practitioners } \\
\text { and } \\
\text { stakeholders }\end{array}$ & $\begin{array}{l}\text { Structural } \\
(\mathrm{Xa})\end{array}$ & $\begin{array}{l}\text { The complexity } \\
\text { related to scale } \\
\text { and interrelation- } \\
\text { ship aspect. }\end{array}$ & $\begin{array}{cc}- & \begin{array}{c}\text { Project goal } \\
\text { - }\end{array} \\
\text { and objectives } \\
\text { - } & \text { Law and } \\
- & \text { regulation } \\
& \text { Task and } \\
- & \text { activity } \\
- & \text { Project site } \\
- & \text { and location } \\
- & \text { Deliverables } \\
- & \text { Schedule } \\
- & \text { Budget } \\
- & \text { Technology } \\
- & \text { Resources } \\
- & \text { Organizatio } \\
& \text { n Team structure }\end{array}$ & \multirow{3}{*}{$\begin{array}{l}\text { Maylor \& Turner } \\
\text { (2017); Othman } \\
\text { (2013), Rolstadås } \\
\text { \& Schiefloe } \\
\text { (2017); Rad et al. } \\
\text { (2017); He et al. } \\
\text { (2015); } \\
\text { Gerhard \& } \\
\text { Christian (2008); } \\
\text { Bosch-Rekveldt et } \\
\text { al. (2011), Kardes } \\
\text { et al. (2013); } \\
\text { Chapman (2016) }\end{array}$} & 0.704 \\
\hline & & Social (Xb) & $\begin{array}{l}\text { The complexity } \\
\text { related to the } \\
\text { human factors } \\
\text { such as teams and } \\
\text { stakeholders with } \\
\text { cultural and } \\
\text { political aspects }\end{array}$ & 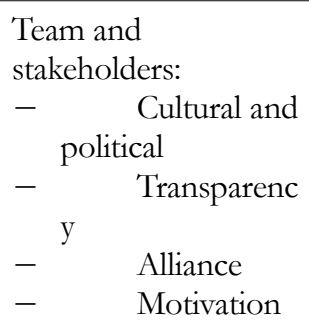 & & 0.673 \\
\hline & & $\begin{array}{l}\text { Emergent } \\
(\mathrm{Xc})\end{array}$ & $\begin{array}{l}\text { The complexity } \\
\text { related to the } \\
\text { change and } \\
\text { uncertainty in the } \\
\text { project }\end{array}$ & $\begin{array}{l}\text { Change and } \\
\text { uncertainty in: } \\
-\quad \text { Structural } \\
\text { aspects } \\
-\quad \text { Social } \\
\text { aspects }\end{array}$ & & 0.801 \\
\hline \multirow{3}{*}{$\begin{array}{l}\text { Leadership } \\
\text { competency } \\
\text { (Z) }\end{array}$} & \multirow{3}{*}{$\begin{array}{l}\text { Combination } \\
\text { of knowledge } \\
\text { (qualification, } \\
\text { skills (ability to } \\
\text { do a task) and } \\
\text { core } \\
\text { personality } \\
\text { characteristics } \\
\text { (motives, traits, } \\
\text { and self- } \\
\text { concepts) that } \\
\text { lead to superior } \\
\text { results. }\end{array}$} & $\begin{array}{l}\text { Technical } \\
(\mathrm{Za})\end{array}$ & $\begin{array}{l}\text { Competencies in } \\
\text { procedural, } \\
\text { alignment, and } \\
\text { exploitation } \\
\text { activity }\end{array}$ & $\begin{array}{ll}- & \text { Procedural } \\
- & \text { Alignment } \\
- & \text { Exploitation }\end{array}$ & $\begin{array}{l}\text { Dulewicz \& Higgs } \\
\text { (2005); PMI } \\
\text { (2017); Uhl-Bien } \\
\text { \& Arena (2018) }\end{array}$ & 0.750 \\
\hline & & $\begin{array}{l}\text { Emotional- } \\
\text { social (Zb) }\end{array}$ & $\begin{array}{l}\text { Competencies in } \\
\text { self-management } \\
\text { and social } \\
\text { management }\end{array}$ & $\begin{array}{lc}- & \text { Self- } \\
& \text { awareness } \\
- & \text { Self-control } \\
- & \text { Social } \\
& \text { awareness } \\
- & \text { Social } \\
& \text { control }\end{array}$ & $\begin{array}{l}\text { Dulewicz \& Higgs } \\
\text { (2005); Hopper } \\
\text { (2010); Boyatzis \& } \\
\text { Goleman (2011) }\end{array}$ & 0.779 \\
\hline & & $\begin{array}{l}\text { Adaptive } \\
(\mathrm{Zc})\end{array}$ & $\begin{array}{l}\text { Competencies in } \\
\text { being flexible, } \\
\text { having } \\
\text { exploration } \\
\text { capability, and } \\
\text { reflex intuitive }\end{array}$ & $\begin{array}{cc}- & \text { Adaptation } \\
- & \text { Exploration } \\
- & \text { (for innovation) } \\
- & \text { Instinctive }\end{array}$ & $\begin{array}{l}\text { Yukl \& Mahsud, } \\
\text { (2010); Uhl-Bien } \\
\text { \& Arena (2018); } \\
\text { Dulewicz \& Higgs } \\
\text { (2005) }\end{array}$ & 0.772 \\
\hline
\end{tabular}




\begin{tabular}{|c|c|c|c|c|c|c|}
\hline Variable & Definition & $\begin{array}{l}\text { Causal } \\
\text { Condition }\end{array}$ & $\begin{array}{l}\text { Operational } \\
\text { Definition }\end{array}$ & Attributes & References & $\begin{array}{c}\text { The } \\
\text { Cronbach } \\
\text { Score }\end{array}$ \\
\hline \multirow{2}{*}{$\begin{array}{l}\text { Megaproject } \\
\text { performance } \\
\text { (Y) }\end{array}$} & \multirow{2}{*}{$\begin{array}{l}\text { Megaproject } \\
\text { outcome for } \\
\text { the short-and } \\
\text { long-term }\end{array}$} & $\begin{array}{l}\text { Short-term } \\
\text { (Y1) }\end{array}$ & $\begin{array}{l}\text { Performance in } \\
\text { terms of } \\
\text { timeliness of } \\
\text { completion, } \\
\text { conformity of } \\
\text { the budget with } \\
\text { planning, and } \\
\text { conformity of } \\
\text { the quality } \\
\text { specifications }\end{array}$ & $\begin{array}{cc}- & \text { Time } \\
- & \text { Cost } \\
- & \text { Quality } \\
& \text { specification }\end{array}$ & $\begin{array}{l}\text { Flyvbjerg (2014); } \\
\text { He et al. (2015); } \\
\text { Locatelli et al. } \\
\text { (2017) }\end{array}$ & 0.679 \\
\hline & & $\begin{array}{l}\text { Long-term } \\
\text { (Y2) }\end{array}$ & $\begin{array}{l}\text { Performance in } \\
\text { terms of people } \\
\text { satisfaction, } \\
\text { economic and } \\
\text { business, } \\
\text { community } \\
\text { welfare, } \\
\text { long-term safety } \\
\text { environment, and } \\
\text { knowledge }\end{array}$ & $\begin{array}{cc}- & \text { People } \\
- & \text { satisfaction } \\
- & \text { Economic } \\
- & \text { or Business } \\
- & \text { Society } \\
- & \text { benefit } \\
- & \text { Constructio } \\
& \text { n organization } \\
\text { benefit }\end{array}$ & $\begin{array}{l}\text { Flyvbjerg (2014); } \\
\text { Sato \& Chagas Jr } \\
\text { (2014); Zhou \& } \\
\text { Mi (2017); (Zeng } \\
\text { et al., 2015) }\end{array}$ & 0.827 \\
\hline
\end{tabular}

Table 1. The Variables and Attributes (Final Version)

Document exploration, which is defined as a secondary data collection approach, has helped in analyzing the interview and questionnaire findings (Neuman, 2007). This study used project document archives, project progress reports, and news obtained from the project's official website.

\subsubsection{Data Processing}

Data were processed using the fsQCA 3.1 software package developed by Ragin and Davey (2017). For data processing, five steps (summarized in Figure 1) were adapted from Berg-Schlosser and De Meur (2009) and Mendel and Korjani (2013) as follows:

\subsubsection{Preparing the Data Set}

In this step, the responses to the questionnaire were tabulated. Using the non-weighted summated scale method, the items under the same variable were summed and its average calculated to obtain an aggregate score. This process was supported by Microsoft Excel.

\subsubsection{Formulating the Furay-set Calibration}

In this step, causal conditions and outcomes were used as fuzzy variables to determine the membership function (Mendel \& Korjani, 2013). There were two mechanisms to perform calibration, i.e., direct and indirect. This study used the direct method calibration to determine the fuzzy membership function thresholds as the megaproject complexity, leadership competence, and performance were not yet identified as a strong empirical basis for formulating a separate (indirect) threshold scale.

\subsubsection{Formulating the Truth Table}

The truth table was structured to display the overall configuration of the megaproject's complexity and leadership competence for assessing the short-term and long-term outcome in high and low performance. Conditions categorized as full membership indicate that the condition "presence" is symbolized by 1, which in this study is interpreted as a "high" condition. If the conditions are included in the non-full membership category with a symbol 0, it indicates "absence," which is interpreted as a "low" condition. These memberships are based on the cutoff threshold that has been determined in the fuzzy calibration process. 


\subsubsection{Formulating the Final Truth Table for the Configuration Result}

The final configuration solution can be determined via three mechanisms: parsimony, intermediate, and complex. In this study, all combinations that happen in cases empirically, both "presence" and "absent" conditions are considered as the configuration. Hence, the complex solution option is used to obtain the solution combination. This step obtains the consistency and coverage score of the solution combined with megaproject complexity and leadership competency in megaproject performance outcomes.

Similar to variable significance in statistical models (Wagemann \& Schneider, 2010), consistency refers to the extent to which empirical evidence supports the set theory claims (Rihoux \& Ragin, 2009). This consistency is often used to determine the combination of causal conditions that are sufficient and necessary for an outcome. In the fsQCA approach, the causal condition combination could be "sufficient but unnecessary" or "necessary but insufficient." A combination condition is sufficient but unnecessary if it is capable of producing the outcome, but it is not the only cause (Ragin \& Davey, 2017); in other words, other causal conditions are needed to produce the outcome. A causal condition is necessary but insufficient if it is capable of producing an outcome in combination with other conditions and appears in all such combinations (Ragin \& Davey, 2017).

If the raw consistency score is above 0.80 , a combination of causal conditions is stated for consistency in producing the outcome (Ragin \& Davey, 2017). Additionally, the causal condition combinations are consistent empirically if they meet the frequency threshold of cases. When less than ten empirical cases are involved, Rihoux and Ragin (2009) recommend using one case as the frequency threshold for the number of cases. Furthermore, if the consistency score exceeds 0.90 , the causal condition is deemed necessary (but insufficient) for producing the outcome (Ragin, 2014).

Besides consistency, the configuration can be explained using the coverage score. This is similar to $\mathrm{R}^{2}$ in the statistical method of regression analysis (Ragin, 2006). However, coverage in fsQCA is descriptive of the real conditions of a case; therefore, there is no minimum coverage score for a configuration to be considered "good" (Korjani \& Mendel, 2012).

\subsubsection{Formulating the Solution Configuration and Necessary Condition}

The purpose of this stage is to extract a parsimonious explanation for an outcome based on the combination condition (Cronqvist \& Berg-Schlosser, 2009) by removing causal conditions with low necessity scores or looking for conditions that meet the requirements (but are insufficient) (consistency score >0.90) (Rihoux \& De Meur, 2009; Ragin, 2014). Visually, a condition becomes necessary (but insufficient) if it is always present in any combination solution for an outcome. Thus, in terms of theoretical and practical implications, the condition obtained from the minimization stage potentially attracts more attention. Because the strength of fsQCA is in conjunctural combination conditions, this necessary condition is in the combination form and cannot be separated from other conditions (Rihoux \& De Meur, 2009). This should be emphasized, especially during the interpretation stage.

\subsubsection{Interpretation}

The configuration of a combination of sufficient (but not necessary) and necessary (but insufficient) causal conditions is often interpreted based on the theory and facts in the examined megaproject cases. This stage serves as a validation and verification process for the configuration, which in this study was discussed with megaproject experts in Indonesia including follow-up interviews with respondents (as explained in the data collection sub-section). The interview guideline is presented in Appendix C.

\section{Result and Discussion}

This section presented the result of the data processing along with the configurational analysis and the research finding and contribution.

\subsection{Data and Fuzzy-Set Calibration}

Research data were prepared using Microsoft Excel according to the mechanism in the Methodology section and were processed using fsQCA 3.1 software. Table 2 presents the data set for this study. In this data set, the 
maximum, average, and minimum values of complexity, leadership competence, and megaproject performance outcome were calculated for fuzzy calibration process.

Using the direct method for calibration, this study's threshold includes non-full membership with a fuzzy score of 0.05, full membership with a score of 0.95 , and membership crossover points (moderate cross with fuzzy scores, 0.5) (Ragin, 2008). To determine the fuzzy threshold, after each variable condition was calculated on the data set, the distribution results were examined based on deviations and ranges (Ragin, 2008; Rihoux \& Ragin, 2009). In this study, fuzzy-set anchors of full membership and full non-membership were based on the maximum and minimum range values for each main condition; the average value range was considered as the crossover point.

As provided in Table 2, for the complexity conditions, the minimum value was 2.00 , the average was 2.86 , and the maximum was 4.14. The thresholds for complexity condition were set at 2 for non-full membership, 3 for the crossover point, and 4 for the full membership. For leadership competency condition, the minimum value was 5.90, the mean was 6.46, and the maximum was 7.00. Thus, 6 was set as the threshold for non-full membership, 6.5 for crossover and 7 for full membership.

For the short-term outcome, the minimum score was 2.13, the mean was 4.14, and the maximum was 6.00 . Therefore, the criteria for non-full membership were set to 2 , the crossover point 4, and full membership 6. For long-term success targets, the scores of the minimum, mean, and maximum values were 5, 5.84 and 6.14, respectively. For the threshold, 5 was set as the non-full membership, 5.5 for the crossover, and 6 as the full membership.

Finally, given that the fsQCA cannot address the so-called maximum ambiguity, to avoid excluding the megaproject cases from the analysis, the crossover point was raised or lowered by 0.01 (Kort, Verweij \& Klijn, 2016). Maximum ambiguity was a difficult condition for determining the membership function, whether full membership or non-full membership. In the direct method, maximum ambiguity tended to occur when the condition value was the same as the crossover value; thus, the case is referred to as "ambiguous," regardless of the inclusion of the full membership criteria (Fiss, 2011). In this study, the crossover threshold point would be lowered by 0.01 . Score value in parentheses shown in Table 3 are final fuzzy thresholds for full membership, cross over, and non-full membership.

Having determined the threshold value, the data set was transformed into fuzzy continuous values using the fsQCA 3.1 software package. The fuzzy calibration result is shown in Table 3. The "f" notation on each label (e.g., fXa; $\mathrm{fXb}$, etc.) is a fuzzy value after calibration.

\begin{tabular}{|c|c|c|c|c|c|c|c|c|}
\hline \multirow[b]{3}{*}{ Megaproject } & \multicolumn{6}{|c|}{ Causal Condition } & \multicolumn{2}{|c|}{ Outcome } \\
\hline & \multicolumn{3}{|c|}{ Complexity } & \multicolumn{3}{|c|}{ Leadership Competency } & \multirow{2}{*}{$\begin{array}{c}\begin{array}{c}\text { Short-term } \\
\text { performance }\end{array} \\
\text { Y1 }\end{array}$} & \multirow{2}{*}{$\begin{array}{c}\begin{array}{c}\text { Long-term } \\
\text { performance }\end{array} \\
\text { Y2 }\end{array}$} \\
\hline & $\mathrm{Xa}$ & $\mathrm{Xb}$ & $\mathrm{Xc}$ & $\mathrm{Za}$ & $\mathrm{Zb}$ & $\mathrm{Zc}$ & & \\
\hline Trans-S & 2.42 & 2.4 & 3.59 & 6.2 & 6.7 & 6.71 & 4 & 6.07 \\
\hline Trans-J & 2.47 & 2.8 & 3.54 & 6.4 & 7 & 6.57 & 4 & 6.14 \\
\hline ILRT-Jt & 3.24 & 2.7 & 3.86 & 5.9 & 6.6 & 6.71 & 4.66 & 5.92 \\
\hline ICMT & 2.80 & 2.1 & 3.72 & 6 & 6.4 & 6.14 & 3.66 & 5.5 \\
\hline Trans-L & 3 & 3 & 3.36 & 6.4 & 6.3 & 6 & 2.13 & 5 \\
\hline LRT-P & 3.28 & 2.2 & 4.14 & 6.5 & 6.6 & 6.57 & 4.33 & 6.14 \\
\hline IIA & 2.14 & 2 & 2.45 & 6.8 & 6.8 & 6.85 & 6 & 6.07 \\
\hline Max value & & & 4.14 & & & 7.00 & 6 & 6.14 \\
\hline Mean value & & & 2.86 & & & 6.46 & 4.14 & 5.84 \\
\hline Min value & & & 2.00 & & & 5.90 & 2.13 & 5.00 \\
\hline
\end{tabular}

Table 2. The Original Data Set 


\begin{tabular}{|c|c|c|c|c|c|c|c|c|}
\hline \multicolumn{6}{|c|}{ Causal Condition } & \multicolumn{2}{|c|}{ Outcome } & \multirow[b]{3}{*}{ Case } \\
\hline \multicolumn{3}{|c|}{$\begin{array}{l}\text { Complexity } \\
(4 ; 2.99 ; 2)\end{array}$} & \multicolumn{3}{|c|}{$\begin{array}{l}\text { Leadership Competency } \\
\qquad(7 ; 6.49 ; 6)\end{array}$} & \multirow{2}{*}{$\begin{array}{l}\text { Short-term } \\
\text { performance } \\
(6 ; 3.99 ; 2) \\
\text { fY1 }\end{array}$} & \multirow{2}{*}{$\begin{array}{l}\text { Long-term- } \\
\text { performance } \\
(6 ; 5.49 ; 5) \\
\text { fY2 }\end{array}$} & \\
\hline $\mathrm{fXa}$ & $\mathbf{f X b}$ & $\mathbf{f X c}$ & $\mathrm{fZa}$ & $\mathbf{f} Z \mathbf{b}$ & $\mathrm{fZc}$ & & & \\
\hline 0.15 & 0.14 & 0.86 & 0.14 & 0.77 & 0.79 & 0.5 & 0.97 & Trans-S \\
\hline 0.17 & 0.36 & 0.84 & 0.37 & 0.95 & 0.62 & 0.5 & 0.98 & Trans-J \\
\hline 0.68 & 0.29 & 0.93 & 0.03 & 0.66 & 0.79 & 0.73 & 0.93 & ILRT-Jt \\
\hline 0.37 & 0.06 & 0.9 & 0.05 & 0.37 & 0.11 & 0.38 & 0.51 & ICMT \\
\hline 0.51 & 0.51 & 0.75 & 0.37 & 0.24 & 0.05 & 0.08 & 0.05 & Trans-L \\
\hline 0.71 & 0.08 & 0.97 & 0.51 & 0.66 & 0.62 & 0.63 & 0.98 & LRT-P \\
\hline 0.07 & 0.05 & 0.16 & 0.86 & 0.86 & 0.9 & 0.95 & 0.97 & IIA \\
\hline
\end{tabular}

Table 3. The Fuzzy Calibration

\subsection{Truth Table}

After the fuzzy score is calibrated, a truth table can be made. Possible combinations in the truth table were $2^{k}$ rows, where $k$ is the number of causal conditions. Each row indicates a possible configuration combination, comprising 1 and 0. A fuzzy membership with a minimum value of 0.5 (crossover point) indicates that a causal condition is more "in-set" than "out-set;" thus, it tends to symbolize a full membership that is [1]. If the membership score is less than 0.5 , then it tends to symbolize non-full membership that is [0]. As previously explained, symbol [1] indicates the presence of a certain condition or outcome, which in this study is termed as "high" (condition or outcome), whereas [0] indicates the absence which is termed as "low".

This study examined six causal conditions-three complexity and three leadership-toward each outcome (i.e., short-term and long-term outcomes in low and high performance). Therefore, the truth table can consist of 64 ( $\left.2^{6}\right)$ possible condition combinations. However, not all combinations are preserved in the final table. It has been explained in the data processing section that to compile a final truth table configuration, a combination of conditions for the outcome must have a minimum consistency value of 0.80 and at least one empirical case. Based on these boundaries, six solution combinations exceeded the threshold consistency $(\geq 0.80)$ and the frequency threshold of cases (at least one). The final truth table is shown in Table 4.

\begin{tabular}{|c|c|c|c|c|c|c|c|c|c|c|c|c|c|c|c|}
\hline \multirow[b]{2}{*}{ Combination } & \multicolumn{3}{|c|}{ Complexity } & \multicolumn{3}{|c|}{$\begin{array}{l}\text { Leadership } \\
\text { Competencies }\end{array}$} & \multicolumn{4}{|c|}{ Performance } & \multicolumn{4}{|c|}{ Raw Consistency } & \multirow[b]{2}{*}{ Case } \\
\hline & $\mathrm{fXa}$ & $\mathrm{fXb}$ & $\mathrm{fXc}$ & $\mathrm{f} Z \mathrm{a}$ & $\mathrm{fZb}$ & $\mathrm{fZc}$ & fY1 & $\sim \mathrm{fY} 1$ & $\mathrm{fY} 2$ & $\sim f Y 2$ & $\mathrm{fY} 1$ & $\sim \mathrm{fY} 1$ & $\mathrm{fY} 2$ & $\sim \mathrm{fY} 2$ & \\
\hline Solution 1 & 0 & 0 & 0 & 1 & 1 & 1 & 1 & 0 & 1 & 0 & 1 & 0.39 & 1 & 0.18 & IIA \\
\hline Solution 2 & 1 & 0 & 1 & 1 & 1 & 1 & 1 & 0 & 1 & 0 & 1 & 0.44 & 1 & 0.23 & ILRT-P \\
\hline Solution 3 & 1 & 0 & 1 & 0 & 1 & 1 & 1 & 0 & 1 & 0 & 1 & 0.69 & 1 & 0.19 & ILRT-Jt \\
\hline Solution 4 & 0 & 0 & 1 & 0 & 1 & 1 & 1 & 0 & 1 & 0 & 0.83 & 0.77 & 1 & 0.14 & $\begin{array}{l}\text { Trans-S; } \\
\text { Trans-J }\end{array}$ \\
\hline Solution 5 & 0 & 0 & 1 & 0 & 0 & 0 & 0 & 1 & 0 & 0 & 0.66 & 0.97 & 0.72 & 0.58 & ICMT \\
\hline Solution 6 & 1 & 1 & 1 & 0 & 0 & 0 & 0 & 1 & 0 & 0 & 0.60 & 1 & 0.58 & 0.67 & Trans-L \\
\hline
\end{tabular}

Table 4. The Final Truth Table

Table 4 identifies the combination of complexity and leadership competence in the "high" [1] and "low" [0] conditions on short-term high performance $(\mathrm{Y} 1)$; short-term low performance ( $\sim$ Y1); long-term high performance (Y2); and long-term low performance ( Y2). For example, in the ILRT-Jt case (combination solution 3), the fuzzy scores (from Table 3) for the conditions of structural ( $\mathrm{fXa}$ ), social (fXb), and emergent (fXc) complexities have been determined to be $0.68,0.29$, and 0.93 respectively. Only the structural ( $\mathrm{fXa}$ ) and emergent complexity (fXc) 
conditions are above 0.5 ; hence, these two complexity conditions are in a "high" condition, which is symbolized by [1]. As the fuzzy score of social complexity (fXb) is under 0.5 , hence, it is defined as "low" condition, which is symbolized by [0]. The same mechanism also applies in calibrating the fuzzy scores of leadership competency conditions.

For megaproject performance outcomes, analyses were carried out based on the raw consistency value for the outcome. The outcome with raw consistency $\geq 0.80$ was categorized as "high" with [1] and vice versa. For example, in ILRT-Jt (combination solution 3), the raw consistency score for short- and long-term high performance (fY1 and $\mathrm{fY} 2$ ) are 1; therefore, the performance outcome in the truth table is symbolized by [1].

\subsection{Configurational Results and Interpretation}

Besides consistency, the solution combination is analyzed based on the values of coverage, which equaled the proportion of the outcome that could be explained by the condition combination. This study used fsQCA 3.1 software in formulating the coverage and consistency values, which were then arranged into a configurational matrix (shown in Figure 3). This matrix is referred to from Table 4, the final truth table. Taking into consideration the study conducted by Ragin and Fiss (2008), the symbols used in the matrix to describe the configuration are as follows: a black circle $(\bullet)$, which indicates the presence of a high condition, and a white circle $(0)$, which indicates the absence of a condition (low).

The configurational result and analysis for megaproject high and low performance in the short and long term are discussed as follows.

\begin{tabular}{|c|c|c|c|c|c|c|c|c|c|c|c|c|c|c|}
\hline \multirow{3}{*}{$\begin{array}{l}\text { High } \\
\text { Performance } \\
\text { Configuration }\end{array}$} & \multicolumn{3}{|c|}{ Complexity } & \multicolumn{3}{|c|}{$\begin{array}{l}\text { Leadership } \\
\text { Competency }\end{array}$} & \multicolumn{4}{|c|}{$\begin{array}{l}\text { Raw Solution for high } \\
\text { performance outcome }\end{array}$} & \multicolumn{4}{|c|}{$\begin{array}{l}\text { Overall Solution for high } \\
\text { performance outcome }\end{array}$} \\
\hline & \multirow[t]{2}{*}{$\mathrm{Xa}$} & \multirow[t]{2}{*}{$\mathrm{Xb}$} & \multirow[t]{2}{*}{ Xc } & \multirow[t]{2}{*}{$\mathrm{Za}$} & \multirow[t]{2}{*}{$\mathrm{Zb}$} & \multirow[t]{2}{*}{ Zc } & \multicolumn{2}{|c|}{ Consistency } & \multicolumn{2}{|c|}{ Coverage } & \multicolumn{2}{|c|}{ Consistency } & \multicolumn{2}{|c|}{ Coverage } \\
\hline & & & & & & & Y1 & $\mathrm{Y} 2$ & Y1 & $\mathrm{Y} 2$ & Y1 & $\mathrm{Y} 2$ & Y1 & Y2 \\
\hline Combination 1 & $C$ & & & & & & 1 & 1 & 0.34 & 0.24 & 0.89 & 1 & 0.87 & 0.66 \\
\hline Combination 2 & & & & & & & 1 & 1 & 0.49 & 0.34 & & & & \\
\hline Combination 3 & & & & & & & 1 & 1 & 0.49 & 0.24 & & & & \\
\hline Combination 4 & O & 0 & & & & & 0.83 & 1 & 0.65 & 0.24 & & & & \\
\hline \multirow{3}{*}{$\begin{array}{l}\text { Low } \\
\text { Performance } \\
\text { Configuration }\end{array}$} & & & & & & & \multicolumn{4}{|c|}{$\begin{array}{l}\text { Raw Solution for low } \\
\text { performance outcome }\end{array}$} & \multicolumn{4}{|c|}{$\begin{array}{l}\text { Overall Solution for low } \\
\text { performance outcome }\end{array}$} \\
\hline & & & & & & & \multicolumn{2}{|c|}{ Consistency } & \multicolumn{2}{|c|}{ Coverage } & \multicolumn{2}{|c|}{ Consistency } & \multicolumn{2}{|c|}{ Coverage } \\
\hline & Xa & $\mathrm{Xb}$ & $\mathrm{Xc}$ & $\mathrm{Za}$ & $\mathrm{Zb}$ & Zc & $\sim Y 1$ & $\sim Y 2$ & $\sim \gamma 1$ & $\sim \gamma 2$ & $\sim \gamma 1$ & $\sim \gamma 2$ & $\sim \gamma 1$ & $\sim Y 2$ \\
\hline $\begin{array}{l}\text { Combination } 1 \\
\text { Combination } 2 \\
\end{array}$ & & & & $\checkmark$ & O & 0 & $\begin{array}{c}0.97 \\
1 \\
\end{array}$ & $\begin{array}{l}0.58 \\
0.67\end{array}$ & $\begin{array}{l}0.59 \\
0.34\end{array}$ & $\begin{array}{l}\text { N/A } \\
\text { N/A }\end{array}$ & 0.91 & N/A & 0.66 & N/A \\
\hline
\end{tabular}

Figure 3. The Configurational Matrix

\subsubsection{Megaproject High Performance}

Figure 3 indicates four solutions of causal condition combination that has been determined to be consistent in producing high outcomes in short (Y1) and long-term (Y2) megaproject performance. It was indicated from solution consistency and coverage score. For short-term high performance (Y1), the raw consistency value ranging from 0.83 to 1 with solution consistency is 0.89 . These results exceeded the threshold value of 0.80 , which is categorized as high consistency. These four causal condition combinations have solution coverage of 0.87 for short-term high performance, with its raw coverage ranging from 0.34 to 0.65 .

These four solutions also exhibited high consistency for long-term high performance (Y2), with raw and solution consistency scores at 1 . These causal condition combinations have raw coverage ranging from 0.24 to 0.34 , with a solution coverage score of 0.66 . These results indicate that the four causal condition combinations are sufficient (but unnecessary) to obtain high performance for megaprojects in the short and long terms.

Besides formulating the configuration solution, the fsQCA also extracts the combination solution by minimizing (synthesizing) the necessary condition. Based on the four solutions of high megaproject performance, three conditions always exist in the given configurations: low social complexity (Xb), high emotional-social competency $(\mathrm{Zb})$, and high adaptive competency $(\mathrm{Zc})$. Hence, these conditions were checked whether they are the necessary (but insufficient) conditions: a condition that must exist in combination to produce an outcome (Ragin, 2014). These 
conditions were checked using fsQCA 3.1 software. As per the results, the scores for low social complexity, high emotional-social competency, and high adaptive competency were $0.994695,0.954907$, and 0.904509 , respectively (exceeded the consistency necessary condition threshold that is $\geq 0.90$ ). Therefore, in this study, these three conditions are deemed "necessary" in every solution combination for high megaproject performance outcomes.

As the solutions are consistent for both short and long-term, only the term "performance" is used for the interpretation of the four combination conditions. As explained in the research methodology, the configuration solution interpretation was based on theory (past research); further, verification was performed via discussion with Indonesia megaproject experts and through follow-up interviews with the megaproject respondents. This is an attempt to validate the configuration results by looking deeper into the aspects of megaprojects not just in Indonesia but in other countries as well.

The first solution combination is when the megaproject has a low structural, social, and emergent complexity condition, which was eventually addressed via its high technical, emotional-social, and adaptive leadership competencies simultaneously. The IIA megaproject conformed to this solution. However, for high performance, the three complexities were not all required to be low with high leadership competencies. In the second solution, conditions of structural and emergent complexities were determined to be high, except for social complexity; however, this was eventually overcome via high technical, emotional-social, and adaptive-flexible competencies simultaneously. This configuration was confirmed to the ILRT-P megaproject.

The third configuration held conditions of high structural and emergent complexities but low social complexity, which was managed by low structural competency combined with high emotional-social and adaptive competencies. This combination of conditions was sufficient to achieve high performance, as indicated in the ILRT-Jt megaproject.

The fourth configuration held conditions of low structural and social complexities but high in emergent complexity, which were eventually managed with high emotional-social and adaptive project manager leadership competencies but low technical competencies. In other words, in case of high emergent complexity, while the other (i.e., structural and social complexity) were low, the megaproject manager's high emotional-social and adaptive competency are sufficient to achieve the megaproject high performance. This fourth solution combination reflects in the cases of Trans-S and Trans-J.

Further, the interpretation of three necessary conditions, namely low social complexity, the high project manager leadership competencies for emotional-social and adaptive aspects. Low social complexity was a necessary condition for high performance. This study revealed that megaprojects in Indonesia had several critical social problems: for instance, community conflict arising from a land acquisition in Trans-J and Trans-S megaprojects, the community lawsuits due to pollution and environmental disturbance, and the intrateam conflict between local construction organization and foreign consultant related to work contract lawsuit in ILRT-Jt megaproject.

All managers strictly consider the social aspects in maintaining the conduciveness of the project. Project managers concurred that reducing conflicts among teams, partners, clients, suppliers, community members, and other stakeholders is important to ensure that cost, schedule, and performance targets were met. Therefore, the social management approach was adopted to overcome social complexity among the stakeholders and the project team. This approach proposes the principle of human relations, which emphasizes emotional management and other creative humanist approaches, such as communication, negotiation, diplomacy, trust, and cultural understanding. This result is consistent with those of other global megaprojects, such as the high-speed railroad construction megaprojects in China (Wu et al., 2015), construction megaprojects in Thailand (Toor \& Arain 2012), and oil and gas projects in Norway (Rolstadås \& Schiefloe, 2017), all of which used strategies involving stakeholders management with a humanism creative approach to overcoming social problems.

To maintain low social complexity, managers make use of their emotional-social competencies, such as interpersonal skills (Arnold, Fletcher \& Molyneux, 2012; Mazur et al., 2014) and an informal approach (Zheng, Lu \& Chang, 2019). Therefore, high emotional-social competency is the second necessary condition for highperformance megaproject configurations. This study has also found that emotional-social leadership competency can be used to manage structural and emergent complexities. 
Most of the megaprojects in Indonesia are the first of their kind in the country (e.g., ILRT-Jt, ILRT-P, and Trans-L); thus, it was no surprise when all the project managers shared that it was their first time being a top/leader/main manager for a megaproject. Some acknowledged their lack of high technical understanding in the field (ILRT-Jt, Trans-J, Trans-S, and Trans-L). Thus, several megaprojects (e.g., ILRT-Jt) have been performed in coordination with foreign consultant partners for the planning (schedules, activities, and risk mitigation) along with project control and evaluation. Some project managers also relied on technical managers and engineers who are highly competent in technical aspects (ILRT-P, IIA, Trans-J, Trans-S, and Trans-L). Therefore, they emphasize the importance of selecting the right team members (technical managers and lead engineers) and managing them appropriately (integration and alignment) using a social approach (emotional-social competency), which is consistent with the construction megaproject in India, Sri Lanka, and Panama (Sankaran, 2018); the construction of the Denver International Airport in the USA (van Johnston, 2011); and the Hong Kong-Zhuhai-Macao Bridge megaproject in China (Qiu et al., 2019). All these studies reported technical problems; however, the social approach, which was deemed inseparable from the management strategies, was used to overcome these complexities.

Emotional-social competency was also used in addressing any emergent complexity (change and uncertainty). In megaprojects, given their novelty (e.g., technology, methods, team experience, and stakeholders), managers often have high emergent complexity. Emotional and social control is also deemed essential for addressing fast-changing issues and uncertainty, which were exhibited by IIA and ILRT-Jt project managers during interviews. Project managers with good self and social control are more confident in achieving targets in the face of uncertainty. Mazur et al. (2014) showed similar results based on the Australian military defense megaproject case study, which exhibited that emotional intelligence helps project leaders achieve flexibility; further, this will be of great aid in overcoming any change and uncertainty through social engagement with the stakeholders.

High adaptive competency is the third necessary condition for achieving high megaproject performance and addressing emergent complexity. Besides, this competency helps overcome high structural complexity, for instance, in ILRT-P and ILRT-Jt megaprojects. Most project managers have found the LRT technology completely new, with its application requiring innovation (e.g., the ILRT-Jt long-span bridge, U-shaped girder technology, and the LRT electricity system).

The project managers should provide "space" to produce creative context for the team, wherein they can share knowledge and learn as a group. This can support the certainty of technological innovation for any emergent complexity and further address structural complexity, including regulating supply materials, discussing acceleration of project work related to schedule adjustments and project resource requirements, harmonizing teams, and integrating all activities to comprehensively coordinate the megaproject. A similar management approach was adopted in the Hong Kong-Zhuhai-Macau Bridge in China (Chen et al., 2018) and in large project-based organizations such as textile mills, tobacco companies, mobile telecommunication companies, and information technology companies in Pakistan (Raziq et al., 2018).

\subsubsection{Megaproject Low Performance}

Regarding a megaproject's low performance, two combination solutions were identified for short-term ( Y1), with a raw coverage value ranging from 0.34 and 0.59 , and the raw consistency ranging from 0.97 and 1 . The values of solution coverage and consistency were 0.66 and 0.91 , respectively (Figure 3).

The first combination was the condition having high emergent complexity (Xc) and low social (Xb) and structural (Xa) complexities, while the three leadership competencies were deemed lower. This configuration was indicated in the ICMT megaproject. Meanwhile, the second combination entails that three complexity conditions (i.e., structural, social, and emergent) were high, but all three leadership competencies were lower, such as in the case of the Trans-L megaproject. As the outcome could be produced by not only one causal condition combination, these results indicated that these configurations are sufficient (but unnecessary) for the short-term low performance. However, this study did not find any solution combination condition that is consistent for long-term low performance $(\sim \mathrm{Y} 2)$ due to the raw consistency of these two combinations being $<0.80$.

Based on the two solutions of short-term low megaproject performance, four conditions always exist in the configurations, namely high emergent complexity and lower leadership competencies in structural, emotional-social, 
and adaptive. However, after checking each condition consistency using fsQCA 3.1 software, only high emergent complexity and low structural leadership competency become the necessary conditions for the short-term low megaproject performance due to the consistency value of 0.947 and 0.910 , respectively. Whereas low leadership competencies in emotional-social and adaptive were not as necessary condition due to the necessary consistency score being 0.718 and 0.854 , respectively (under the threshold of the necessary conditions of 0.90 ).

By looking closely into field facts, in the cases of ICMT and Trans-L, the obtained explanation was that high emergent complexity was inseparable from structural, technical (including technology, design, and finance), and social aspects (stakeholder and politics). This was perceived to be the main aspect attributed to falling short of time and cost targets. This is not only in Indonesia; similar problems occur in other megaprojects around the world.

Changes that are difficult to anticipate can have a significant impact on a project, especially on its budget and schedule. This is a reality for most megaprojects; for example, in a railroad construction project in the UK (Chapman, 2016), in an energy infrastructure construction project in Europe (Rad et al., 2017), and a construction project in India (Iyer \& Jha, 2006). In contrast to megaprojects, changes in ordinary projects tend to be linear and predictable, thus moderating possible effects caused by management planning and risk mitigation is possible (Kardes et al., 2013). Meanwhile, some changes in megaprojects, especially in terms of technical and social aspects, imply nonlinear processes and uncertain impacts.

In Indonesia, ICMT and Trans-L have been identified as two of the few projects having new design and technology applications perceived to have high uncertainty, for instance, the implementation of the tunnel boring machine (ICMT) for the underground construction phase and the construction of the longest elevated toll road in Indonesia (Trans-L). Additionally, ICMT is a project that has been ongoing for three decades. Several constructions have been implemented in these decades before finally being completed in 2015, therefore requiring significant alignment.

In Trans-L, technical issues have been identified to have significant impacts (e.g., removing surplus high voltage airways that can potentially disturb the whole nation's electricity). Another unavoidable problem is related to changes (acceleration) of the project completion time, causing the supply of materials to also accelerate, which can impact congestion and flooding in the construction sector. Schedule adjustments also occur due to the social aspects of the community land disputes (Trans-L and ICMT). Some changes to the project completion happened, while construction sections were not ready and this impacted the structural complexity (scheduling and cost adjusting in Trans-L, etc.).

The ICMT and Trans-L were supported by professional teams. For the ICMT, the main contracting organization's commitment was also high, as they provided training overseen by experts with experience organizing underground and elevated construction projects (ICMT). Additional knowledge and intensive training from developed countries with higher mastery of technology have also proven successful in supporting several megaprojects in Sri Lanka, Malaysia, Nigeria, Thailand, South Africa, and Colombia (Kumaraswamy, 1998). However, for the Trans-L project, there was no special training process.

Positive and negative social-political impacts will go hand in hand. For instance, the national government supports project implementations in ICMT and Trans-L (positive), but sometimes those projects require accommodating certain parties (negative). This applies not only to Indonesia but also to other megaprojects, including those in Peru (Strauch, Takano \& Hordijk, 2015), China (Liu, Zhu, Wang \& Huang, 2016), Algeria (Zidane et al., 2013), and Finland (Ruuska et al., 2009).

In this fact-deepening activity, it can be concluded that project managers used all potential, knowledge, skills in the technical and social (communication, coordination, and negotiation) fields of the project and were endeavoring to adapt to changes. However, those project managers admitted that, at the time, they could not independently carry the project without support from foreign consulting experts (ICMT). It was stated by the manager (Trans-L) that the added knowledge received from training in specific project areas handled by project managers was essential, especially for large, innovative projects. The uncertainty condition in megaprojects, caused by deficiencies in knowledge and experience not only occurs in Indonesia but is also a typical problem for construction organizations in developing countries like Sri Lanka (Santoso \& Gallage, 2019), Iran (Hosseini, Banihashemi, Martek, Golizadeh \& Ghodoosi, 2018), and Thailand (Prasitsom \& Likhitruangsilp, 2015b). 


\subsubsection{Research Finding}

This study found that a high-performance megaproject did not (always) need all three high leadership competencies to address the given complexities. Similarly, with the three megaproject complexities, although the conditions can be high and low, megaprojects can still be successful. This is consistent with the fsQCA conjunctural principle (Ragin, 2014), which asserts that a single condition cannot explain/predict an outcome; thus, it should be analyzed in combination with other conditions (Kirchherr, Charles \& Walton, 2016). Thus, the three leadership competencies must be simultaneously considered along with the aspects of complexity to better explain/predict the outcome of the megaproject.

This study also revealed that the configurations of high performance were not contrary to those for low performance. For example, when simultaneous conditions of high structural, low social, and high emergent complexities are addressed with a combination of low technical leadership competencies, high emotional-social, and high adaptive skills, it can lead to high-performance megaprojects. However, there was no indication in the case observed that combination condition in contrary (e.g., low structural complexity, high social complexity, low emergent complexity combined with the high technical competency, low emotional-social competency, and low adaptive competency) resulted in low performance. This is consistent with the fsQCA asymmetric principle (Ragin, 2014), implying that cases with combined opposite conditions may not produce contrasting outcomes.

The configuration analysis revealed that multiple combinations can lead to a megaproject's success, which is consistent with the fsQCA principle of equifinality (Ragin, 2014), colloquially termed "many roads lead to Rome" (Kirchherr et al., 2016). For instance, when high leadership competencies on all three aspects address the three low complexities, the first solution combination occurs. In the second solution, the three high leadership competencies can simultaneously achieve high performance when structural and emergent complexities are high, while social complexity is low. The third and fourth solutions, with different combinations of solutions, also achieve megaproject success.

This study also found that in lower-performance megaprojects, various combinations of complexities occur (i.e., both low and high), but the managerial leadership competency in all three aspects was low and therefore insufficient for achieving a high level of performance on the megaproject.

Therefore, the main findings can be summarized as follows:

1. This study found four different pathways (sufficient but unnecessary combination condition) for achieving megaproject success both in the short and long term (Y1 and Y2). This finding strengthens the perspective of "one size does not fit all project" by Shenhar (2001), which means that the megaproject management strategy is contingent toward the context (e.g., conditions of complexity and project manager leadership competence) of the megaproject.

2. Three conditions, namely, (1) low social complexity, (2) a megaproject manager with high emotional-social competency, and (3) a megaproject manager with high adaptive competency, were necessary (but insufficient in single condition) for a successful megaproject. This means that these three conditions should be present along with various combinations of structural $(\mathrm{Xa})$ and emergent $(\mathrm{Xc})$ megaproject complexity conditions and technical project manager leadership competencies (Za).

3. Insufficient competence in the technical $(\mathrm{Za})$, emotional-social $(\mathrm{Zb})$, and adaptive $(\mathrm{Zc})$ aspects potentially lead to lower megaproject performance in the short-term $(\sim \mathrm{Y} 1)$, especially when the emergent complexity $(\mathrm{Xc})$ in the megaproject is high and is not addressed with the proper technical leadership competency ( $\mathrm{Za})$.

\subsection{Contribution to the Body of Knowledge Management in Engineering}

This study contributes to the area of megaproject management in four ways. First, it focuses on the management of megaprojects by understanding their complexity. In this study, past research on project and megaproject complexities were reviewed to determine its complexity aspects. The three dimensions of project complexity and its management approaches are further looked into and developed to better conform to megaprojects.

Second, in managing megaprojects by responding to complexity, this study provides an insight into the competencies of megaproject management leadership. This is an important research area for the development of megaproject management theory as it fills theoretical gaps in megaproject management in terms of the leadership aspect. 
Third, this study found four pathways of configuration complexity and leadership competence with three conditions needing to exist to achieve megaproject success. Two pathways that must be considered for low-performing megaprojects were also identified. From here, several findings on areas of management and leadership were revealed with the potential to support megaproject management knowledge, including social complexity management, emergent/dynamic complexity management, and technical, emotional-social, and adaptive competency-based leadership, among others. These various managerial approaches need to be comprehensively combined, integrated, and balanced in the management of megaprojects to achieve success.

Finally, this study applied a relatively new research method in the engineering field especially in the context of megaprojects, that is, fsQCA. This method offers an alternative approach wherein a comparative research design can be utilized for qualitative-quantitative analysis. This method can be utilized for simultaneous multivariable analysis even in a small sample. By using fsQCA, this study proposed an outcome as the combined effect of all variables, namely, the configuration of conjunctural, asymmetric, and equifinality. The multivariable combination in configurational forms such as the fsQCA approach can be analyzed simultaneously and comprehensively.

\section{Conclusion}

This study offers a theoretical and practical findings of megaproject management and provides a comprehensive discussion on combining leadership competencies and the complexity condition to achieve a successful megaproject. Therefore, this study complements previous literature and fills in the research gap on leadership competencies.

Using the fsQCA method, the sufficient (but unnecessary) and necessary (but insufficient) combination conditions were determined. These findings contribute to the literature on megaproject management due to the comprehensive understanding of complexity and conformity of project manager's leadership competencies. Management and leadership theory, which potentially followed up to support megaproject management have been presented in research contribution for management engineering body of knowledge.

This study has also proposed practical implications-for practitioners. Megaprojects can be successful by matching complexity conditions with appropriate leadership competencies. Therefore, a megaproject manager should first understand the complexities to determine the best strategy. To understand the complexity in megaprojects, all three aspects (i.e., structural, social, and technical) should be assessed early in the planning stage.

A strategy should be developed after understanding the complexity via the project manager's self-assessment of leadership competencies to assess its suitability in managing a certain megaproject. Furthermore, this study can be adapted to provide an advanced profiling tool for construction organizations to select new megaproject managers and prepare training programs and megaproject manager knowledge bases.

However, this study has some limitations. First, it only addressed Indonesian megaproject construction cases in the transportation sector. Future research should also examine megaprojects of other fields for more comprehensive insights into the leadership characteristics of successful megaproject managers.

Second, this study examined cases in their final stages and did not capture the unique phenomena related to other megaproject stages. A megaproject runs across multiple years, with each stage potentially having different complexities. Thus, the dynamics of the different stages can be explored further to understand its complexity and the leadership competencies in each megaproject stage. To better understand the changing nature of a megaproject's complexity and leadership competencies, longitudinal studies are needed for further research.

Third, the fsQCA method was sufficient to understand the combination of complexity and leadership competencies in the megaproject performance with small sample cases. However, the fsQCA method can only explain the combination of conditions specific to the existing cases. A combination of conditions cannot be solved if there were no empirical cases. Therefore, the results of this study are temporary and may differ as more empirical cases with different combination conditions are examined. Besides, although fsQCA is a quantitative approach that utilizes Boolean algebra, configuration comparative analysis using small samples was unable to explain results that were more rigorous when compared with the statistical approach. Having a higher sample size and additional analytical approaches that can lead to a more robust quantitative analysis method is strongly needed to address these limitations. Additional multivariable statistical methods, such as SEM, are highly suggested to be applied for future research, along with the configurational approach, to build a grounded megaproject theory. This triangulation 
among statistical and configuration analysis would allow the results to be further generalized against case uniqueness.

\section{Acknowledgment}

The authors would like to thank Enago (www.enago.com) for the English language review.

\section{Declaration of Conflicting Interests}

The authors declared no potential conflicts of interest with respect to the research, authorship, and/or publication of this article.

\section{Funding}

This study is funded by the Doctoral Dissertation Research Grant with a contract number 6/AMD/E1/KP.PTNBH/2020 and 3124/UN1.DITLIT/DIT-LIT/PT/2020, Directorate of Research and Community Service, Directorate General of Research and Technology Strengthening and Development, The Ministry of Research, Technology and Higher Education of the Republic of Indonesia.

\section{References}

Aaltonen, K., \& Kujala, J. (2016). Towards an improved understanding of project stakeholder landscapes. International Journal of Project Management, 34(8), 1537-1552. https://doi.org/10.1016/j.ijproman.2016.08.009

Ahn, S., Shokri, S., Lee, S., Haas, C.T., \& Haas, R.C.G. (2017). Exploratory Study on the Effectiveness of Interface-Management Practices in Dealing with Project Complexity in Large-Scale Engineering and Construction Projects. Journal of Management in Engineering, 33(2), 1-12. https://doi.org/10.1061/(ASCE)ME.1943-5479.0000488

Ahola, T. (2012). Insights to the governance of large projects: Analysis of Organization Theory and Project Management: Administering Uncertainty in Norwegian Offshore Oil by Stinchcombe and Heimer. International Journal of Managing Projects in Business, 5(4), 661-679. https://doi.org/10.1108/17538371211268979

Amoatey, C., \& Hayibor, M. (2017). Critical success factors for local government project stakeholder management. Built Environment Project and Asset Management, 7(2), 143-156. https://doi.org/10.1108/BEPAM-07-2016-0030

Arnold, R., Fletcher, D., \& Molyneux, L. (2012). Performance leadership and management in elite sport: Recommendations, advice and suggestions from national performance directors. European Sport Management Quarterly, 12(4), 317-336. https://doi.org/10.1080/16184742.2012.693115

Babatunde, S.O., Perera, S., Udeaja, C., \& Zhou, L. (2014). Challenges of Implementing Infrastructure Megaprojects through Public-Private Partnerships in Nigeria: A Case Study of Road Infrastructure. International Journal of Architecture, Engineering and Construction, 3(2), 142-154.

Bagozzi, R.P., \& Yi, Y. (1988). On the evaluation of structural equation models. Journal of the Academy of Marketing Science, 16(1), 74-94. https://doi.org/10.1007/BF02723327

Bahadorestani, A., Karlsen, J.T., \& Farimani, N.M. (2020). Novel Approach to Satisfying Stakeholders in Megaprojects: Balancing Mutual Values. Journal of Management in Engineering, 36(2). https://doi.org/10.1061/ (ASCE)ME.1943-5479.0000734

Berg-Schlosser, D., \& De Meur, G. (2009). Comparative research design: case and variable selection. In Rihoux, B., \& Ragin, C.C. (Eds.), Configurational Comparative Methods: Qualitative Comparative Analysis (QCA) and Related Techniques (19-32). Thousand Oaks. SAGE Publications. https://doi.org/10.4135/9781452226569.n2

Bosch-Rekveldt, M., Jongkind, Y., Mooi, H., Bakker, H., \& Verbraeck, A. (2011). Grasping project complexity in large engineering projects: The TOE (Technical, Organizational and Environmental) framework. International Journal of Project Management, 29(6), 728-739. https://doi.org/10.1016/j.ijproman.2010.07.008

Boyatzis, R.E., \& Goleman, D. (2011). Emotional and Social Competency Inventory (ESCI): A user guide for accredited practioners. Hay Group. Available at: http://www.eiconsortium.org/pdf/ESCI_user_guide.pdf

Brady, T., \& Davies, A. (2014). Managing Structural and Dynamic Complexity: A Tale of Two Projects. Project Management Journal, 45(4), 21-38. https://doi.org/10.1002/pmj.21434 
Brahm, F., \& Tarziján, J. (2015). Does complexity and prior interactions affect project procurement? Evidence from mining mega-projects. International Journal of Project Management, 33(8), 1851-1862.

https://doi.org/10.1016/j.ijproman.2015.08.005

Brislin, R. (1970). Back-Translation for Cross-Cultural Research. Journal of Cross-Cultural Psychology, 1(3), $185-216$. https://doi.org/10.1177/135910457000100301

Brockmann, C. (2009). Mega-Projects: Getting the Job Done. LEAD Conference (12).

Callahan, R.F., Pisano, M., \& Linder, A. (2010). Leadership and strategy: A comparison of the outcomes and institutional designs of the Alameda Corridor and Alameda Corridor East projects. Public Works Management and Policy, 14(3), 263-287. https://doi.org/10.1177/1087724X09359629

Chapman, R.J. (2016). A framework for examining the dimensions and characteristics of complexity inherent within rail megaprojects. International Journal of Project Management, 34(6), 937-956. https://doi.org/10.1016/j.ijproman.2016.05.001

Chen, H., Su, Q., Zeng, S., Sun, D., \& Shi, J.J. (2018). Avoiding the innovation island in infrastructure mega-project. Frontiers of Engineering Management, 5(March), 109-124. https://doi.org/10.15302/J-FEM-2018073

Committee for Acceleration of Priority Infrastructure Delivery (2018). National Strategic Projects. Committee for Acceleration of Priority Infrastructure Delivery. Available at: https://kppip.go.id/en/national-strategic-projects/ (Accessed: June 2018).

Cooke-Davies, T. (2011). Aspects of Complexity: Managing Projects in a Complex World (43). Atlanta, USA: Project Management Institute, Inc. https://doi.org/10.1002/pmj.21270

Cronqvist, L., \& Berg-Schlosser, D. (2009). Multi-value qca (mvqca). In Rihoux, B., \& Ragin, C.C. (Eds.), Configurational Comparative Methods: Qualitative Comparative Analysis (QCA) and Related Techniques (51, 69-86). Thousand Oaks: SAGE Publications. https://doi.org/10.4135/9781452226569.n4

Damayanti, R., Hartono, B., \& Wijaya, A. (2019). The Complexity of Megaprojects in Developing Countries: A Literature Review. 2018 IEEE International Conference on Industrial Engineering and Engineering Management (IEEM) (1366-1370). IEEE. https://doi.org/10.1109/IEEM.2018.8607707

Denicol, J., Davies, A., \& Krystallis, I. (2020). What Are the Causes and Cures of Poor Megaproject Performance? A Systematic Literature Review and Research Agenda. Project Management Journal, 51(3), 328-345.

https://doi.org/10.1177/8756972819896113

Denicol, J., Davies, A., \& Pryke, S. (2021). The organisational architecture of megaprojects. International Journal of Project Management, February. https://doi.org/10.1016/j.ijproman.2021.02.002

Di Maddaloni, F., \& Davis, K. (2017). The influence of local community stakeholders in megaprojects: Rethinking their inclusiveness to improve project performance. International Journal of Project Management, 35(8), $1537-1556$. https://doi.org/10.1016/j.ijproman.2017.08.011

Dulewicz, V., \& Higgs, M. (2005). Assessing leadership styles and organisational context. Journal of Managerial Psychology, 20(2), 105-123. https://doi.org/10.1108/02683940510579759_

Finstad, K. (2010). Response interpolation and scale sensitivity: Evidence against 5-point scales. Journal of Usability Studies, 5(3), 104-110.

Fiss, P.C. (2011). Building Better Causal Theories: A Fuzzy Set Approach to Typologies in Organization Research. Academy of Management Journal, 54(2), 393-420. https://doi.org/10.5465/amj.2011.60263120

Flyvbjerg, B. (2013). The Megaprojects Paradox, Interview. Insight, 4, 12-15. Available at: https://www.academia.edu/21818869/The Megaprojects Paradox

Flyvbjerg, B. (2014). What You Should Know About Megaprojects and Why: An Overview. Project Management Journal, 45(2), 6-19. https://doi.org/10.1002/pmj.21409

Flyvbjerg, B., Bruzelius, N., \& Rothengatter, W. (2003). Megaprojects and risk: An anatomy of ambition. Cambridge University Press. https://doi.org/10.1017/CBO9781107050891 
Galvin, P., Tywoniak, S., \& Sutherland, J. (2021). Collaboration and opportunism in megaproject alliance contracts: The interplay between governance, trust and culture. International Journal of Project Management, February. https://doi.org/10.1016/j.ijproman.2021.02.007

Geraldi, J., Maylor, H., \& Williams, T. (2011). Now, let's make it really complex (complicated): A systematic review of the complexities of projects. International Journal of Operations \& Production Management, 31(9), 966-990. https://doi.org/10.1108/01443571111165848

Gerhard, G., \& Christian, B. (2008). The Inherent Complexity of Large Scale Engineering Projects. Project Perspectives, Annual Publication of International Project Management Association, 22-26.

Giezen, M. (2013). Adaptive and strategic capacity: Navigating megaprojects through uncertainty and complexity. Environment and Planning B: Planning and Design, 40(4), 723-741. https://doi.org/10.1068/b38184

Graham, P., Nikolova, N., \& Sankaran, S. (2020). Tension between Leadership Archetypes: Systematic Review to Inform Construction Research and Practice. Journal of Management in Engineering, 36(1), 03119002. https://doi.org/10.1061/(ASCE)ME.1943-5479.0000722

Grün, O. (2004). Taming giant projects: Management of multi-organization enterprises. Springer Science \& Business Media. https://doi.org/10.1007/978-3-540-24818-7

Hair, Jr., J.F., Black, W.C., Babin, B.J., \& Anderson, R.E. (2014). Multivariate Data Analysis (MVDA). Pearson New International Edition (7th ed.). Edinburg: Pearson new International Edition.

Hartono, B., Sulistyo, S.R., Chai, K.H., \& Indarti, N. (2019). Knowledge Management Maturity and Performance in a Project Environment: Moderating Roles of Firm Size and Project Complexity. Journal of Management in Engineering, 35(6). https://doi.org/10.1061/(ASCE)ME.1943-5479.0000705

Hartono, B., Sulistyo, S., \& Umam, M. (2019). Leadership Profiles of Successful Project Managers in Indonesia. Journal of Industrial Engineering and Management, 12(2), 274-301. https://doi.org/10.3926/jiem.2735

He, Q., Luo, L., Hu, Y., \& Chan, A.P.C. (2015). Measuring The Complexity of Mega Construction Projects in China-A fuzzy analytic network process analysis. International Journal of Project Management, 33(3), 549-563. https://doi.org/10.1016/j.ijproman.2014.07.009

Hopper, L. (2010). Mindful Leadership. Georgia Library Quarterly, 47(2), 6-9. Available at: https://digitalcommons.kennesaw.edu/glq/vol47/iss $2 / 6$

Hosseini, M.R., Banihashemi, S., Martek, I., Golizadeh, H., \& Ghodoosi, F. (2018). Sustainable Delivery of Megaprojects in Iran: Integrated Model of Contextual Factors. Journal of Management in Engineering, 34(2), 05017011. https://doi.org/10.1061/(ASCE)ME.1943-5479.0000587

Hsu, S.C., Weng, K.W., Cui, Q., \& Rand, W. (2016). Understanding the complexity of project team member selection through agent-based modeling. International Journal of Project Management, 34(1), 82-93. https://doi.org/10.1016/j.ijproman.2015.10.001

Hu, Y., Chan, A.P.C., \& Le, Y. (2015). Understanding the Determinants of Program Organization for Construction Megaproject Success: Case Study of the Shanghai Expo Construction. Journal of Management in Engineering, 31(5), 05014019. https://doi.org/10.1061/(ASCE)ME.1943-5479.0000310

Hu, Y., Chan, A.P.C., Le, Y., \& Jin, R. (2015). From Construction Megaproject Management to Complex Project Management: Bibliographic Analysis. Journal of Management in Engineering, 31(4), 1-11. https://doi.org/10.1061/ (ASCE)ME.1943-5479.0000254

Ivory, C., \& Alderman, N. (2005). Can Project Management Learn Anything From Studies of Failure in Complex Systems? Project Management Journal, 36(3), 5-16. https://doi.org/10.1177/875697280503600302

Iyer, K.C., \& Jha, K.N. (2006). Critical Factors Affecting Schedule Performance: Evidence from Indian Constrcution Projects. Journal of Construction Engineering and Management, 132(8), 871-881. https://doi.org/10.1061/ (ASCE)0733-9364(2006)132:8(871)

Jia, G., Yang, F., Wang, G., Hong, B., \& You, R. (2011). A study of mega project from a perspective of social conflict theory. International Journal of Project Management, 29(7), 817-827.

https://doi.org/10.1016/j.ijproman.2011.04.004 
Jordan, E., Gross, M.E., Javernick-Will, A.N., \& Garvin, M.J. (2011). Use and misuse of qualitative comparative analysis. Construction Management and Economics, 29(11), 1159-1173. https://doi.org/10.1080/01446193.2011.640339

Kardes, I., Ozturk, A., Cavusgil, S.T., \& Cavusgil, E. (2013). Managing global megaprojects: Complexity and risk management. International Business Review, 22(6), 905-917. https://doi.org/10.1016/j.ibusrev.2013.01.003

Kirchherr, J., Charles, K.J., \& Walton, M.J. (2016). Multi-causal pathways of public opposition to dam projects in Asia: A fuzzy set qualitative comparative analysis (fsQCA). Global Environmental Change, 41, 33-45. https://doi.org/10.1016/j.gloenvcha.2016.08.001

Korjani, M.M., \& Mendel, J.M. (2012). Fuzzy set Qualitative Comparative Analysis (fsQCA): Challenges and applications. 2012 Annual Meeting of the North American Fursy Information Processing Society, NAFIPS 2012. https://doi.org/10.1109/NAFIPS.2012.6291026

Kort, I.M., Verweij, S., \& Klijn, E.H. (2016). In search for effective public-private partnerships: An assessment of the impact of organizational form and managerial strategies in urban regeneration partnerships using fsQCA. Environment and Planning C: Government and Policy, 34(5), 777-794. https://doi.org/10.1177/0263774X15614674

Kumaraswamy, M.M. (1998). Industry development through creative project packaging and integrated management. Engineering Construction \& Architectural Management, 5(3), 228-237. https://doi.org/10.1108/eb021077

Lessard, D., Sakhrani, V., \& Miller, R. (2014). House of Project Complexity-understanding complexity in large infrastructure projects. Engineering Project Organization Journal, 4(4), 170-192.

https://doi.org/10.1080/21573727.2014.907151

Li, Y., Han, Y., Luo, M., \& Zhang, Y. (2019). Impact of Megaproject Governance on Project Performance: Dynamic Governance of the Nanning Transportation Hub in China. Journal of Management in Engineering, 35(3), 05019002. https://doi.org/10.1061/(ASCE)ME.1943-5479.0000681

Li, Y., Lu, Y., Cui, Q., \& Han, Y. (2019). Organizational Behavior in Megaprojects: Integrative Review and Directions for Future Research. Journal of Management in Engineering, 35(4), 04019009. https://doi.org/10.1061/ (ASCE)ME.1943-5479.0000691

Li, Y., Lu, Y., Taylor, J.E., \& Han, Y. (2017). Bibliographic and comparative analyses to explore emerging classic texts in megaproject management. International Journal of Project Management, 36(2), 342-361. https://doi.org/10.1016/j.ijproman.2017.05.008

Liu, Z., Zhu, Z., Wang, H., \& Huang, J. (2016). Handling social risks in government-driven mega project: An empirical case study from West China. International Journal of Project Management, 34(2), 202-218. https://doi.org/10.1016/j.ijproman.2015.11.003

Locatelli, G, Mikic, M., Kovacevic, M., Brookes, N., \& Ivanisevic, N. (2017). The Successful Delivery of Megaprojects: A Novel Research Method. Project Management Journal, 48(5), 78-94. https://doi.org/10.1177/875697281704800506

Lu, Y., Luo, L., Wang, H., Le, Y., \& Shi, Q. (2015). Measurement model of project complexity for large-scale projects from task and organization perspective. International Journal of Project Management, 33(3), 610-622. https://doi.org/10.1016/j.ijproman.2014.12.005

Ma, H., Zeng, S., Lin, H., Chen, H., \& Shi, J.J. (2017). The societal governance of megaproject social responsibility. International Journal of Project Management, 35(7), 1365-1377. https://doi.org/10.1016/j.ijproman.2017.01.012

Marín, G., \& Marín, B. (1991). Applied Social Research Methods: Research with Hispanic populations. Newbury Park, CA: SAGE Publications. https://doi.org/10.4135/9781412985734

Maylor, H.R., Turner, N.W., \& Murray-Webster, R. (2013). How Hard Can It Be?: Actively Managing Complexity in Technology Projects. Research-Technology Management, 56(4), 45-51. https://doi.org/10.5437/08956308X5602125

Maylor, H., \& Turner, N.W. (2017). Understand, reduce, respond: project complexity management theory and practice. International Journal of Operations \& Product, 37(8), 1076-1093. https:// doi.org/10.1108/IJOPM-05-2016-0263

Mazur, A.K., \& Pisarski, A. (2015). Major project managers' internal and external stakeholder relationships: The development and validation of measurement scales. International Journal of Project Management, 33(8), 1680-1691. https://doi.org/10.1016/j.ijproman.2015.07.008 
Mazur, A., Pisarski, A., Chang, A., \& Ashkanasy, N.M. (2014). Rating Defense Mega-Project Success: The: The Role of Personal Attributes and Stakeholder Relationships. International Journal of Project Management, 32(8), 9-13. https://doi.org/10.1016/j.ijproman.2013.10.018

Mendel, J.M., \& Korjani, M.M. (2013). Theoretical aspects of Fuzzy Set Qualitative Comparative Analysis (fsQCA). Information Sciences, 237, 137-161. https://doi.org/10.1016/j.ins.2013.02.048

Müller, M. (2014). Introduction: Winter Olympics Sochi 2014: What is at stake? East European Politics, 30(2), 153-157. https://doi.org/10.1080/21599165.2014.880694

Müller, R., \& Turner, J.R. (2007). Matching the project manager's leadership style to project type. International Journal of Project Management, 25(1), 21-32. https:// doi.org/10.1016/j.ijproman.2006.04.003

Nätti, A.J.T. (2016). Formation of strategic networks under high uncertainty of a megaproject. Journal of Business \& Industrial Marketing, 31(5). https:// doi.org/10.1108/JBIM-03-2014-0055

Neuman, W.L. (2007). Basics of social research: Qualitative and quantitative approaches (2nd ed.). Boston: Pearson Education, Inc.

Ninan, J., Clegg, S., Burdon, S., \& Clay, J. (2021). Overt obstacles and covert causes: An exploratory study of poor performance in megaprojects. Project Leadership and Society, March. https://doi.org/10.1016/j.plas.2021.100011

Othman, A. (2013). Challenges of mega construction projects in developing countries. Organization, Technology and Management in Construction, 5(1), 730-746. https://doi.org/10.5592/otmcj.2013.1.10

Parent, M.M., Olver, D., \& Séguin, B. (2009). Understanding Leadership in Major Sporting Events: The Case of the 2005 World Aquatics Championships. Sport Management Review, 12(3), 167-184.

https://doi.org/10.1016/j.smr.2009.01.004

Pitsis, A., Clegg, S., Freeder, D., Sankaran, S., \& Burdon, S. (2018). Megaprojects redefined - complexity vs cost and social imperatives. International Journal of Managing Projects in Business, 11(1), 7-34. https://doi.org/10.1108/IJMPB-072017-0080

PMI (2017). Project Manager Competency Development Framework. Project Management Institute (3rd ed). Project Management Institute, Inc.

Prasitsom, A., \& Likhitruangsilp, V. (2015a). Effects of Organization Structures on International Construction Joint Venture Risks. Journal of Construction Engineering and Management, 4(4), 128-148.

Prasitsom, A., \& Likhitruangsilp, V. (2015b). Managing Risks in Forming International Construction Joint Ventures in Thailand. International Journal of Construction Engineering and Management, 4(4), 106-121.

Qiu, Y., Chen, H., Sheng, Z., \& Cheng, S. (2019). Governance of institutional complexity in megaproject organizations. International Journal of Project Management, 37(3), 425-443.

https://doi.org/10.1016/j.ijproman.2019.02.001

Rad, E.K., Sun, M., \& Bosché, F. (2017). Complexity for Megaprojects in the Energy Sector. Journal of Management in Engineering, 33(4), 04017009. https://doi.org/10.1061/(ASCE)ME.1943-5479.0000517

Ragin, C.C. (2006). Set relations in social research: Evaluating their consistency and coverage. Political Analysis, 14(3), 291-310. https://doi.org/10.1093/pan/mpj019

Ragin, C.C. (2008). Redesigning Social Inquiry Fuzzy Sets and Beyond (3). Chicago and London: University of Chicago Press. https://doi.org/10.7208/chicago/9780226702797.001.0001

Ragin, C.C. (2014). The Comparative Method: Beyond Qualitative and Quantitative Strategies (2nd ed). Oackland, California: University of California Press. https://doi.org/10.1525/9780520957350

Ragin, C.C., \& Davey, S. (2017). User's guide to fuzzy-set / Qualitative Comparative Analysis. University of California Press.

Ragin, C.C., \& Fiss, P.C. (2008). Net effects analysis versus configurational analysis: An empirical demonstration. In Redesigning social inquiry: Furzy sets and beyond (pp. 190-212). https://doi.org/10.7208/chicago/9780226702797.001.0001 
Raziq, M.M., Borini, F.M., Malik, O.F., Ahmad, M., \& Shabaz, M. (2018). Leadership styles, goal clarity, and project success: Evidence from project-based organizations in Pakistan. Leadership and Organization Development Journal, 39(2), 309-323. https://doi.org/10.1108/LODJ-07-2017-0212

Rihoux, B., \& De Meur, G. (2009). Crisp-Set Qualitative Comparative Analysis (csQCA). In Rihoux, B., \& Ragin, C.C. (Eds.), Configurational Comparative Methods: Qualitative Comparative Analysis (QCA) and Related Techniques (33-67). Thousand Oaks: SAGE Publications. https://doi.org/10.4135/9781452226569

Rihoux, B., \& Ragin, C.C. (2009). Why Compare? Why Configurational Comparative Methods? In Rihoux, B., \& Ragin, C.C. (Eds.), Configurational Comparative Methods: Qualitative Comparative Analysis (QCA) and Related Techniques (xvii-xxv). Thousand Oaks: SAGE Publications. https://doi.org/10.4135/9781452226569

Rolstadås, A., \& Schiefloe, P. (2017). Modelling project complexity. International Journal of Managing Projects in Business, 10(2), 295-314. https://doi.org/10.1108/IJMPB-02-2016-0015

Ruuska, I., Artto, K., Aaltonen, K., \& Lehtonen, P. (2009). Dimensions of distance in a project network: Exploring Olkiluoto 3 nuclear power plant project. International Journal of Project Management, 27(2), 142-153. https://doi.org/10.1016/j.ijproman.2008.09.003

Sankaran, S. (2018). Megaproject management and leadership: a narrative analysis of life stories - past and present. International Journal of Managing Projects in Business, 11(1), 53-79. https://doi.org/10.1108/IJMPB-07-2017-0081

Santoso, D.S., \& Gallage, P.G.M.P. (2019). Critical factors affecting the performance of large construction projects in developing countries: A case study of Sri Lanka. Journal of Engineering, Design and Technology, 18(3), 531-556. https://doi.org/10.1108/JEDT-05-2019-0130

Sato, C., \& Chagas Jr, M. (2014). When do megaprojects start and finish? Redefining project lead time for megaproject success. International Journal of Managing Projects in Business, 7(4), 624-637. https://doi.org/10.1108/IJMPB-07-2012-0040

Shenhar, A., \& Holzmann, V. (2017). The Three Secrets of Megaproject Success: Clear Strategic Vision, Total Alignment, and Adapting to Complexity. Project Management Journal, 48(6), 29-46. https://doi.org/10.1177/875697281704800604

Shenhar, A.J. (2001). One Size Does Not Fit All Projects: Exploring Classical Contingency Domains. Management Science, 47(3), 394-414. https:// doi.org/10.1287/mnsc.47.3.394.9772

Shenhar, A.J. (2004). Strategic Project Leadership Toward a strategic approach to project management. R\&DD Management, 34(5), 569-578. https://doi.org/10.1111/j.1467-9310.2004.00363.x

Strauch, L., Takano, G., \& Hordijk, M. (2015). Mixed-use spaces and mixed social responses: Popular resistance to a megaproject in Central Lima, Peru. Habitat International, 45(P3), 177-184.

https://doi.org/10.1016/j.habitatint.2014.02.005

Toor, S.R., \& Arain, F.M. (2012). The Quadrilateral Model of Leadership: Findings From A Study on A Mega Project. International Journal of Construction Project Management, 4(2), 125-146. Available at: https://search.proquest.com/docview/1711197193/fulltextPDF/E8010BD5761F4C50PQ/1?accountid=13771

Uhl-Bien, M., \& Arena, M. (2018). Leadership for organizational adaptability: A theoretical synthesis and integrative framework. Leadership Quarterly, 29(1), 89-104. https://doi.org/10.1016/j.leaqua.2017.12.009

van Ban, T., \& Hadikusumo, B.H.W. (2017). Culture EPC oil and gas project in Vietnam: grounded theory. International Journal of Energy Sector Management, 11(3), 366-386. https://doi.org/10.1108/IJESM-04-2016-0009

van den Ende, L., \& van Marrewijk, A. (2015). The social construction of cultural differences in a Siberian joint-venture megaproject. Journal of Strategic Contracting and Negotiation, 1(2), 168-185.

https://doi.org/10.1177/2055563615598164

van Johnston, R. (2011). Entrepreneurial megaproject leadership, innovation, and accountability: Denver's international airport, T-REX, and fastracks. Public Works Management and Policy, 16(3), 199-227.

https://doi.org/10.1177/1087724X11409949 
van Marrewijk, A., Clegg, S.R., Pitsis, T.S., \& Veenswijk, M. (2008). Managing public-private megaprojects: Paradoxes, complexity, and project design. International Journal of Project Management, 26(6), 591-600.

https://doi.org/10.1016/j.ijproman.2007.09.007

Wagemann, C., \& Schneider, C.Q. (2010). Qualitative comparative analysis (QCA) and fuzzy-sets: Agenda for a research approach and a data analysis technique. Comparative Sociology, 9(3), 376-396.

https://doi.org/10.1163/156913210X12493538729838

Wan, J., Le, Y., Wang, G., Xia, N., \& Liu, X. (2020). Carrot or stick? The impact of paternalistic leadership on the behavioral integration of top management teams in megaprojects. International Journal of Managing Projects in Business, 13(5), 937-960. https://doi.org/10.1108/IJMPB-12-2019-0302

Wang, T., Chan, A.P.C., He, Q., \& Xu, J. (2020). Identifying the gaps in construction megaproject management research: a bibliographic analysis. International Journal of Construction Management, 4(3), 1-12. https://doi.org/10.1080/15623599.2020.1735610

Wang, Y., Han, Q., de Vries, B., \& Zuo, J. (2016). How the public reacts to social impacts in construction projects? A structural equation modeling study. International Journal of Project Management, 34(8), 1433-1448. https://doi.org/10.1016/j.ijproman.2016.07.008

Wu, C., Fang, D., \& Li, N. (2015). Roles of owners' leadership in construction safety: The case of high-speed railway construction projects in China. International Journal of Project Management, 33(8), 1665-1679. https://doi.org/10.1016/j.ijproman.2015.07.005

Wu, L., Jia, G., \& Zhang, P. (2019). Improving the effectiveness of public participation in public infrastructure megaprojects. International Journal of Managing Projects in Business, 13(7), 1522-1536. https://doi.org/10.1108/IJMPB12-2018-0281

Yukl, G., \& Mahsud, R. (2010). Why flexible and adaptive leadership is essential. Consulting Psychology Journal, 62(2), 81-93. https://doi.org/10.1037/a0019835

Zeng, S.X., Ma, H.Y., Lin, H., Zeng, R.C., \& Tam, V.W.Y. (2015). Social responsibility of major infrastructure projects in China. International Journal of Project Management, 33(3), 537-548.

https://doi.org/10.1016/j.ijproman.2014.07.007

Zheng, X., Lu, Y., \& Chang, R. (2019). Governing Behavioral Relationships in Megaprojects: Examining Effect of Three Governance Mechanisms under Project Uncertainties. Journal of Management in Engineering, 35(5), 04019016. https://doi.org/10.1061/(ASCE)ME.1943-5479.0000701

Zhou, Z., \& Mi, C. (2017). Social responsibility research within the context of megaproject management: Trends, gaps and opportunities. International Journal of Project Management, 35(7), 1378-1390. https://doi.org/10.1016/j.ijproman.2017.02.017

Zidane, Y.J.-T., Johansen, A., \& Ekambaram, A. (2013). Megaprojects-Challenges and Lessons Learned. Procedia Social and Behavioral Sciences, 74, 349-357. https://doi.org/10.1016/j.sbspro.2013.03.041 


\section{Appendix A}

\section{Indonesia Infrastructure Megaproject Case}

\begin{tabular}{|c|c|c|c|c|c|c|c|}
\hline Features & Trans-J & Trans-S & Trans-L & LRT-Jt & LRT-S & ICMT & IIA \\
\hline $\begin{array}{l}\text { 1. Project } \\
\text { scope }\end{array}$ & $\begin{array}{l}\text { Engineering, } \\
\text { procurement, } \\
\text { construction and } \\
\text { commissioning } \\
\text { (EPCC) toll road } \\
\text { works of the } \\
\text { central island } \\
\text { covering a length } \\
\text { of } 325 \mathrm{~km}\end{array}$ & $\begin{array}{l}\text { EPCC toll } \\
\text { road works } \\
\text { of } \\
\text { Indonesia } \\
\text { west island } \\
\text { two } \\
\text { sections } \\
\text { corridors } \\
112 \mathrm{~km} .\end{array}$ & $\begin{array}{l}\text { EPCC toll } \\
\text { road works } \\
\text { of } \\
\text { Indonesia } \\
\text { metropolis } \\
\text { city six } \\
\text { sections } \\
\text { corridors } \\
36.4 \mathrm{~km} \text {. }\end{array}$ & $\begin{array}{l}\text { EPCC works } \\
\text { of seven } \\
\text { corridors of } \\
\text { LRT over a } \\
\text { total length } \\
\text { of } 81.5 \mathrm{~km} \text {, } \\
\text { including the } \\
\text { infrastructure } \\
\text { system }\end{array}$ & $\begin{array}{l}\text { EPCC works } \\
\text { of eight } \\
\text { corridors of } \\
\text { LRT over a } \\
\text { total length } \\
\text { of } 23 \mathrm{~km} \text {, } \\
\text { including the } \\
\text { infrastructure } \\
\text { system }\end{array}$ & $\begin{array}{l}\text { EPCC works } \\
\text { of } 5.7 \mathrm{~km} \text { with } \\
13 \text { stations } \\
\text { (7 elevated } \\
\text { stations and six } \\
\text { underground } \\
\text { stations) } \\
\text { (for phase 1) } \\
81 \mathrm{~km} .\end{array}$ & $\begin{array}{l}\text { EPCC } \\
\text { works to } \\
\text { the area of } \\
\text { the airport } \\
\text { reaches } \\
58.652 \mathrm{~m}^{2} \text {. }\end{array}$ \\
\hline $\begin{array}{l}\text { 2. Cost } \\
\text { Investment }\end{array}$ & $\begin{array}{l}\text { Plan: \$US } 1.8 \\
\text { billion; } \\
\text { Realization: \$US } \\
1.9 \text { billion }\end{array}$ & $\begin{array}{l}\text { Plan: \$US } \\
1.15 \text { billion. } \\
\text { Realization: } \\
\text { \$US } 1.2 \\
\text { billion }\end{array}$ & $\begin{array}{l}\text { Plan: \$US } \\
0.8 \text { billion. } \\
\text { Realization: } \\
\text { \$US } 0.95 \\
\text { billion }\end{array}$ & $\begin{array}{l}\text { Plan: } \$ 1.3 \\
\text { billion. } \\
\text { Realization: \$ } \\
\text { US } 1.4 \text { billion }\end{array}$ & $\begin{array}{l}\text { Plan: } \$ 0.73 \\
\text { billion. } \\
\text { Realization: \$ } \\
\text { US } 0.9 \text { billion }\end{array}$ & $\begin{array}{l}\text { Plan: \$ } 1.07 \\
\text { billion. } \\
\text { Realization: \$ } \\
\text { US } 1.13 \text { billion }\end{array}$ & $\begin{array}{l}\text { Plan: } \\
\text { \$US138 } \\
\text { million. } \\
\text { Realization: } \\
\text { \$ US 130 } \\
\text { million. }\end{array}$ \\
\hline 3. Duration & $\begin{array}{l}\text { Started in April } \\
2016 . \\
\text { Completion in } \\
\text { December } 2018\end{array}$ & $\begin{array}{l}\text { Started in } \\
\text { May } 2016 . \\
\text { Completio } \\
\mathrm{n} \text { in } \\
\text { December } \\
2019\end{array}$ & $\begin{array}{l}\text { Start in } \\
2017 . \\
\text { Completion } \\
\text { in } \\
\text { November } \\
2019\end{array}$ & $\begin{array}{l}\text { Start in Jan } \\
2015 . \\
\text { Completion } \\
\text { in mid-2019 }\end{array}$ & $\begin{array}{l}\text { Start in } \\
\text { March } 2016 . \\
\text { Completion } \\
\text { in October } \\
2018\end{array}$ & $\begin{array}{l}\text { Start in } 2013 . \\
\text { Completion in } \\
2019 \text { (ICMT } \\
\text { phase 1) }\end{array}$ & $\begin{array}{l}\text { Start in } \\
\text { November } \\
2016 . \\
\text { Completion } \\
\text { in April } \\
2018\end{array}$ \\
\hline
\end{tabular}

\section{Appendix B}

\section{Leadership for Megaproject Complexity Questionnaire}

\section{Section A - General Information}

Instructions:

Section A consists of 3 sub-sections, these include the respondent's contact information, the respondent's profile, and megaproject profile. You are requested to fill in these sub-sections.

1. Respondent Contact Information*

(* It is optional to fill in, but if you want to get an executive summary of the survey results in the form of a soft file please enter your e-mail address)

a. Name:

b. Phone-number:

c. E-mail:

2. Respondent Profile

a. Company

name:

b. Expertise

certification:

c. How long have you been working in this company (year):

d. Your experience and position in the previous megaproject:


3. Megaproject Profile

(If you have managed more than one megaproject, please choose one from your experience for this survey)
a. Name
of
megaproject:

b. The

cost

c. The

duration

(e.g.,

January

2018

March

d. The project's current stage:

\section{Section B - The Megaproject Complexity}

Instructions:

Section B assesses the complexity of the megaproject experiences specified above. You are requested to respond to the statements, as there are no "right" and "wrong" answers to these statements. Respond based on your personal perception.

There are seven (7) choice scales for responding to statements with the following information:

(1) $=$ I completely agree

(2) $=$ I agree

(3) = I somewhat agree

(4) $=$ I am indifferent

(5) $=$ I somewhat disagree

(6) $=$ I do not agree

(7) $=$ I strongly disagree

The following statement is the condition of this project. Please select one by giving checkmark on the appropriate columns.

\begin{tabular}{|c|c|c|c|c|c|c|c|c|}
\hline \multicolumn{9}{|c|}{ The structural complexity } \\
\hline No & Statement & 1 & 2 & 3 & 4 & 5 & 6 & 7 \\
\hline 1. & There is clarity of the project objectives & & & & & & & \\
\hline 2. & There is clarity of the project human resource contract & & & & & & & \\
\hline 3. & There is clarity of the regulation for the project implementation & & & & & & & \\
\hline 4. & There is clarity of scope of the project & & & & & & & \\
\hline 5. & The project team are familiar with the project's natural environment & & & & & & & \\
\hline 6. & There is clarity of the quality target specifications & & & & & & & \\
\hline 7. & $\begin{array}{l}\text { The pace of project work is appropriately planned to meet the } \\
\text { target time }\end{array}$ & & & & & & & \\
\hline 8. & There is clarity of human resource planning & & & & & & & \\
\hline 9. & The progress report can be informed to the client on time & & & & & & & \\
\hline 10. & There is sufficient budget to complete the project & & & & & & & \\
\hline 11. & There is clarity of the project's financial administration procedures & & & & & & & \\
\hline 12. & There is flexible usage of the project budget & & & & & & & \\
\hline 13. & The team is familiar with the technology (the existence of new technology) & & & & & & & \\
\hline 14. & $\begin{array}{l}\text { The project's resources (e.g., management software and equipment } \\
\text { facilities) needed are available }\end{array}$ & & & & & & & \\
\hline 15. & $\begin{array}{l}\text { There is appropriate supply of materials based on the project's } \\
\text { requirements }\end{array}$ & & & & & & & \\
\hline
\end{tabular}




\begin{tabular}{|c|c|c|c|c|c|c|c|c|}
\hline \multicolumn{9}{|c|}{ The structural complexity } \\
\hline No & Statement & 1 & 2 & 3 & 4 & 5 & 6 & 7 \\
\hline 16. & $\begin{array}{l}\text { The project is implemented in one region (country, time zone, and } \\
\text { language) }\end{array}$ & & & & & & & \\
\hline 17. & $\begin{array}{l}\text { The project manager has the authority over the human resources } \\
\text { allocated to the project }\end{array}$ & & & & & & & \\
\hline 18. & The project team understands the responsibility flow and its targets & & & & & & & \\
\hline 19. & There is need for cross-discipline knowledge integration & & & & & & & \\
\hline 20. & $\begin{array}{l}\text { There are human resources with the proper skills to complete the } \\
\text { project }\end{array}$ & & & & & & & \\
\hline 21. & The project is independent of other projects & & & & & & & \\
\hline
\end{tabular}

\begin{tabular}{|c|c|c|c|c|c|c|c|c|}
\hline \multicolumn{9}{|c|}{ The social complexity } \\
\hline No & Statement & 1 & 2 & 3 & 4 & 5 & 6 & 7 \\
\hline 1. & $\begin{array}{l}\text { Clarity of the business process is formulated by all involved entities } \\
\text { (client, partners, stakeholder, shareholders, and supplier) }\end{array}$ & & & & & & & \\
\hline 2. & There is clarity of the stakeholders' importance (clients and sponsors) & & & & & & & \\
\hline 3. & $\begin{array}{l}\text { The project objectives aligned with the goals of the contracting } \\
\text { organization }\end{array}$ & & & & & & & \\
\hline 4. & $\begin{array}{l}\text { There is synergy and commitment among all project stakeholders } \\
\text { (clients and sponsors) }\end{array}$ & & & & & & & \\
\hline 5. & $\begin{array}{l}\text { The senior management in the contracting organization supports } \\
\text { the project implementation }\end{array}$ & & & & & & & \\
\hline 6. & $\begin{array}{l}\text { The differences in the organizational work culture do not inhibit } \\
\text { the project }\end{array}$ & & & & & & & \\
\hline 7. & $\begin{array}{l}\text { The team are familiar with the local community culture in the } \\
\text { project area }\end{array}$ & & & & & & & \\
\hline 8. & There is high project team motivation & & & & & & & \\
\hline 9. & The teamwork conditions support target achievement & & & & & & & \\
\hline 10. & The project's core team has authority in decision-making & & & & & & & \\
\hline
\end{tabular}

\begin{tabular}{|c|c|c|c|c|c|c|c|c|}
\hline \multicolumn{9}{|c|}{ The emergent complexity } \\
\hline No & Statement & 1 & 2 & 3 & 4 & 5 & 6 & 7 \\
\hline 1. & There is no regulation change for project implementation & & & & & & & \\
\hline 2. & The project objective is consistent from the beginning & & & & & & & \\
\hline 3. & The project scope is steady & & & & & & & \\
\hline 4. & The project success criteria do not change & & & & & & & \\
\hline 5. & The project schedule does not change & & & & & & & \\
\hline 6. & $\begin{array}{l}\text { The available resources (material, management tool, facilities, and } \\
\text { equipment) are stable }\end{array}$ & & & & & & & \\
\hline 7. & There is no acceleration in the pace of project work & & & & & & & \\
\hline 8. & The available project budget availability is stable & & & & & & & \\
\hline 9. & There is consistency in the financial administration procedures & & & & & & & \\
\hline
\end{tabular}




\begin{tabular}{|c|c|c|c|c|c|c|c|c|}
\hline \multicolumn{9}{|c|}{ The emergent complexity } \\
\hline No & Statement & 1 & 2 & 3 & 4 & 5 & 6 & 7 \\
\hline 10. & There are no technology updates during the project & & & & & & & \\
\hline 11. & $\begin{array}{l}\text { The project manager's authority is stable from the beginning for } \\
\text { human resource arrangement }\end{array}$ & & & & & & & \\
\hline 12. & The allocation of key person in the project is stable & & & & & & & \\
\hline 13. & $\begin{array}{l}\text { The appropriate human resource skills for the project are } \\
\text { consistent }\end{array}$ & & & & & & & \\
\hline 14. & The team responsibilities and tasks in the project are constant & & & & & & & \\
\hline 15. & The stability of project team motivation is high & & & & & & & \\
\hline 16. & The harmony of teamwork is stable & & & & & & & \\
\hline 17. & $\begin{array}{l}\text { The project objectives are always aligned with the organizational } \\
\text { goals }\end{array}$ & & & & & & & \\
\hline 18. & The contractor's organizational structure does not change & & & & & & & \\
\hline 19. & The project business processes are stable & & & & & & & \\
\hline 20. & $\begin{array}{l}\text { The support from senior management is consistent in the project } \\
\text { implementation }\end{array}$ & & & & & & & \\
\hline 21. & $\begin{array}{l}\text { The commitment of the client and sponsors to the project is } \\
\text { consistent }\end{array}$ & & & & & & & \\
\hline 22. & The project core team authority is stable with the decision-making & & & & & & & \\
\hline
\end{tabular}

\section{Section C - The Leadership Competency}

Instructions:

The section $\mathrm{C}$ assesses the leadership competency on one of the megaproject experiences specified above. You are requested to provide response on the competencies used to manage this project, as there are no "right" and "wrong" answers to these statements. Provide responses based on your personal perception.

Seven (7) scales are available for responding to statements megaproject leadership competencies, namely:

(1) = I strongly disagree

(2) $=$ I do not agree

(3) = I somewhat disagree

(4) $=$ I am indifferent

(5) $=$ I somewhat agree

(6) $=$ I agree

(7) $=$ I strongly agree

The following statements deal with the competencies you used in this project. Please select one by giving checkmark on the appropriate columns.

\begin{tabular}{|c|c|c|c|c|c|c|c|c|}
\hline \multicolumn{9}{|c|}{ The technical competency } \\
\hline No & Statement & 1 & 2 & 3 & 4 & 5 & 6 & 7 \\
\hline 1. & Identifying project objectives & & & & & & & \\
\hline 2. & $\begin{array}{l}\text { Formulating contingency plans to diagnose potential problems/risks } \\
\text { as well as arrange relevant actions for the project }\end{array}$ & & & & & & & \\
\hline 3. & $\begin{array}{l}\text { Management planning (schedule, technical resources, and buman / team } \\
\text { resources) is comprehensively carried out }\end{array}$ & & & & & & & \\
\hline 4. & $\begin{array}{l}\text { Executing the project accountability properly and in accordance with } \\
\text { the planning targets }\end{array}$ & & & & & & & \\
\hline
\end{tabular}




\section{The technical competency}

\begin{tabular}{|c|c|c|c|c|c|c|c|c|}
\hline No & Statement & 1 & 2 & 3 & 4 & 5 & 6 & 7 \\
\hline 5. & Managing the project team properly (controlling and directing) & & & & & & & \\
\hline 6. & Controlling the activities according to the project target & & & & & & & \\
\hline 7. & Possessing adequate technical knowledge in the project field & & & & & & & \\
\hline 8. & Solving the various arising problems comprehensively & & & & & & & \\
\hline 9. & $\begin{array}{l}\text { Aligning with project activities, technical resources, and human } \\
\text { resources }\end{array}$ & & & & & & & \\
\hline 10. & $\begin{array}{l}\text { Optimizing the current project capacity (tools, methods/ knowledge, } \\
\text { resources, and human resources) }\end{array}$ & & & & & & & \\
\hline
\end{tabular}

\begin{tabular}{|c|c|c|c|c|c|c|c|c|}
\hline \multicolumn{9}{|c|}{ The emotional social competency } \\
\hline No & Statement & 1 & 2 & 3 & 4 & 5 & 6 & 7 \\
\hline 1. & Self-understanding (emotions, strengths, and weaknesses) & & & & & & & \\
\hline 2. & Self-controlling (stress and emotional reaction) & & & & & & & \\
\hline 3. & Being consistent (in harmony with beliefs/values, words, and behavior) & & & & & & & \\
\hline 4. & Self-focusing on achieving project targets & & & & & & & \\
\hline 5. & Self-motivating (positive thinking) & & & & & & & \\
\hline 6. & Taking responsibility without blaming others & & & & & & & \\
\hline 7. & Adapting to the different organizations' work culture & & & & & & & \\
\hline 8. & Building social networks (teams, clients, sponsors, and stakeholders) & & & & & & & \\
\hline 9. & $\begin{array}{l}\text { Mastering the communication methods for diplomacy and } \\
\text { negotiation }\end{array}$ & & & & & & & \\
\hline 10. & Having the confidence to lead the project team facing a crisis & & & & & & & \\
\hline
\end{tabular}

\begin{tabular}{|c|c|c|c|c|c|c|c|c|}
\hline \multicolumn{9}{|c|}{ The adaptive competency } \\
\hline No & Statement & 1 & 2 & 3 & 4 & 5 & 6 & 7 \\
\hline 1. & Adjusting to change quickly & & & & & & & \\
\hline 2. & $\begin{array}{l}\text { Managing the transition of change (anticipating the impacts, balancing } \\
\text { action-reaction, and short-and long-term considerations) }\end{array}$ & & & & & & & \\
\hline 3. & The ability to build trust and commitment to new strategies & & & & & & & \\
\hline 4. & The ability to explain to project entities about changing & & & & & & & \\
\hline 5. & Innovating (technical and social) & & & & & & & \\
\hline 6. & $\begin{array}{l}\text { Integrating innovation (balancing/aligning it with other innovations and } \\
\text { current conditions) }\end{array}$ & & & & & & & \\
\hline 7. & Facilitating for organizational learning (brainstorming and discussion) & & & & & & & \\
\hline
\end{tabular}

\section{Section D - The Megaproject Performance}

Instructions:

The section $\mathrm{D}$ assesses the short and long-term performance of the project specified above. You are requested to respond to these statements based on your personal perception, as there are no "right" and "wrong" answers.

Seven (7) scales are available for responding to statements megaproject performance, namely: 
(1) $=$ I strongly disagree

(2) $=$ I do not agree

(3) = I somewhat disagree

(4) $=\mathrm{I}$ am indifferent

(5) $=$ I somewhat agree

(6) $=$ I agree

(7) = I strongly agree

The following statement is reflecting this megaproject performance. Please select one by giving checkmark on the appropriate columns.

\begin{tabular}{|c|c|c|c|c|c|c|c|c|}
\hline \multicolumn{9}{|c|}{ The short-term performance } \\
\hline No & Statement & 1 & 2 & 3 & 4 & 5 & 6 & 7 \\
\hline 1. & This project is on-time & & & & & & & \\
\hline 2. & This project is on-budget & & & & & & & \\
\hline 3. & This project is on-target (construction, design, security and safety & & & & & & & \\
\hline
\end{tabular}

\begin{tabular}{|c|c|c|c|c|c|c|c|c|}
\hline \multicolumn{9}{|c|}{ The long-term performance } \\
\hline No & Statement & 1 & 2 & 3 & 4 & 5 & 6 & 7 \\
\hline 1. & $\begin{array}{l}\text { The projects fulfill the long-term SHE standards (safety, health, and } \\
\text { environment) }\end{array}$ & & & & & & & \\
\hline 2. & The clients are satisfied & & & & & & & \\
\hline 3. & The suppliers are satisfied & & & & & & & \\
\hline 4. & The partners (including NGO partners) are satisfied & & & & & & & \\
\hline 5. & The team is satisfied & & & & & & & \\
\hline 6. & The public/community is satisfied & & & & & & & \\
\hline 7. & It has an economic benefit to the surrounding community & & & & & & & \\
\hline 8. & The project is beneficial for the long-term national economy/business & & & & & & & \\
\hline 9. & It benefits the business of shareholders & & & & & & & \\
\hline 10. & It benefits the business of contracting organizations & & & & & & & \\
\hline 11. & The project benefits the contractor's long-term partnership & & & & & & & \\
\hline 12. & $\begin{array}{l}\text { It is beneficial for the development of civilization (including social, } \\
\text { cultural, or environmental aspects) }\end{array}$ & & & & & & & \\
\hline 13. & The project became a symbol of national pride & & & & & & & \\
\hline 14. & $\begin{array}{l}\text { Projects result in the development of technology / knowledge / } \\
\text { experience / intellectual capital for construction organizations }\end{array}$ & & & & & & & \\
\hline
\end{tabular}

\section{Appendix C}

\section{Interview Guideline}

\section{Part I - Megaproject Complexity}

\begin{tabular}{|l|l|l|l|}
\hline No & \multicolumn{1}{|c|}{ Aspect } & \multicolumn{1}{|c|}{ Question List } & Check List \\
\hline \multirow{4}{*}{1.} & Structural complexity & Describe the complexity challenges associated with: & \\
\cline { 3 - 4 } & & a. Project objectives & \\
\hline & b. Project organization & \\
\cline { 3 - 4 } & c. Megaproject scope / scale & \\
\cline { 3 - 4 } & d. Cost / administration & \\
\hline
\end{tabular}




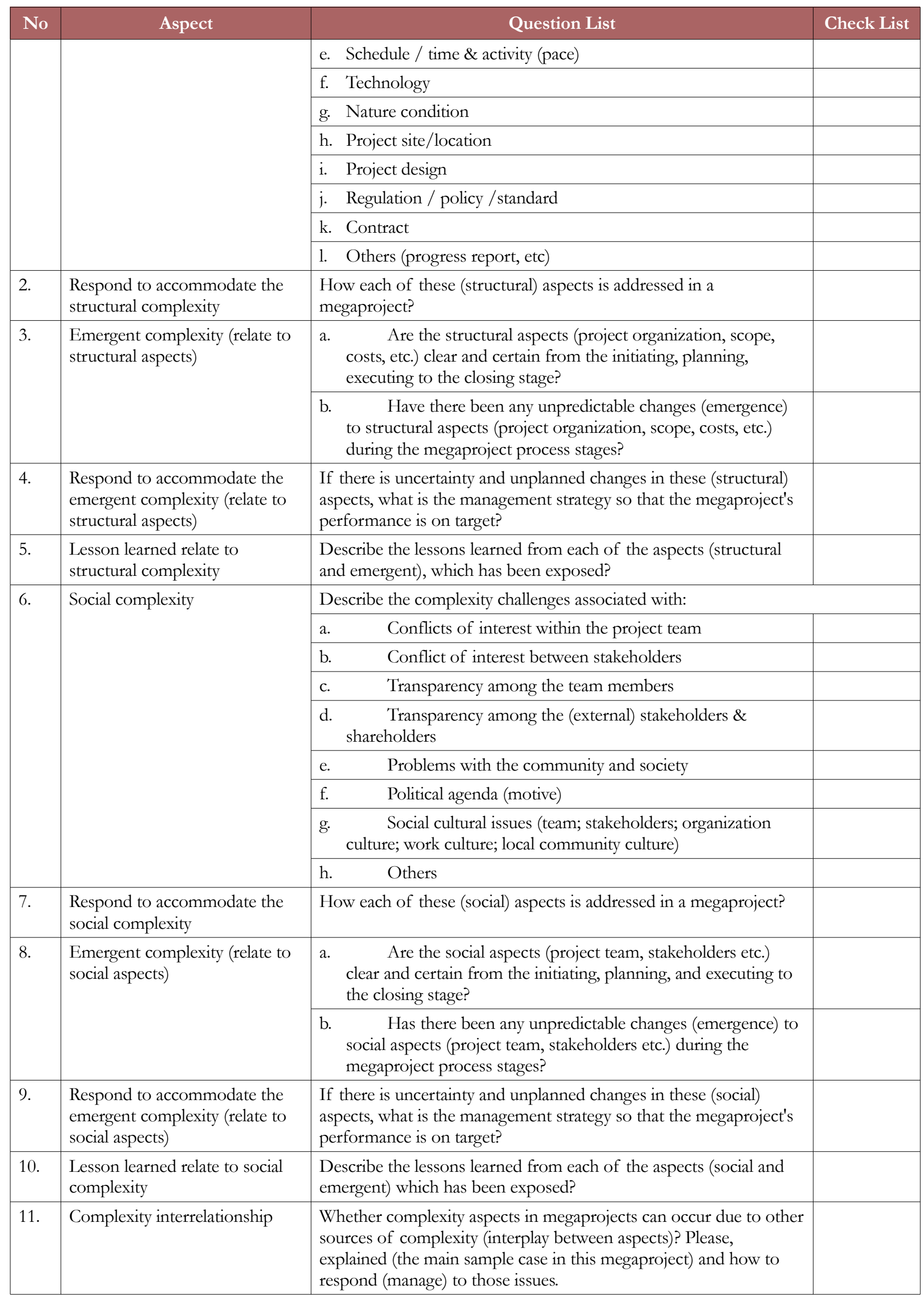




\begin{tabular}{|c|c|c|c|}
\hline No & Aspect & Question List & Check List \\
\hline \multirow[t]{4}{*}{12.} & \multirow{4}{*}{$\begin{array}{l}\text { Complexity and megaproject } \\
\text { performance }\end{array}$} & \multicolumn{2}{|l|}{ Do you agree with this statement? And please explained: } \\
\hline & & $\begin{array}{l}\text { If the social (cultural and political) conditions/aspects of } \\
\text { the team and stakeholders can be managed/anticipated, the } \\
\text { megaproject has greater potential for success (short term and } \\
\text { long term). }\end{array}$ & \\
\hline & & $\begin{array}{l}\text { If internal and external conditions are relatively stable, } \\
\text { megaprojects have a greater potential for success (short term } \\
\text { and long term). }\end{array}$ & \\
\hline & & $\begin{array}{l}\text { If the conditions / structured aspects (task procedures, } \\
\text { schedule, and organization) are well coordinated, the megaproject } \\
\text { can achieve its targets successfully (short term and long term). }\end{array}$ & \\
\hline
\end{tabular}

\section{Part II - Leadership Competency}

\begin{tabular}{|c|c|c|c|}
\hline No & Aspect & Question List & Check List \\
\hline 1. & Technical competency & $\begin{array}{l}\text { Whether a top project manager needs to have high leadership } \\
\text { competence to manage technical aspects? (please, explained). }\end{array}$ & \\
\hline 2. & Emotional Social competency & $\begin{array}{l}\text { Whether a top project manager needs to have high leadership } \\
\text { competencies to manage the social-emotional aspects (self- } \\
\text { management and relationships between teams and stakeholders)? } \\
\text { (please, explained). }\end{array}$ & \\
\hline 3. & Adaptive competency & $\begin{array}{l}\text { Do you agree that a top project manager needs to have high } \\
\text { adaptive (agile) leadership competencies? (please, explained). }\end{array}$ & \\
\hline \multirow[t]{2}{*}{4.} & \multirow[t]{2}{*}{$\begin{array}{l}\text { Leadership competency } \\
\text { combination }\end{array}$} & $\begin{array}{l}\text { Whether the leadership competencies of megaproject } \\
\text { managers (especially top managers) need to be mutually } \\
\text { combined during the megaproject implementation process? }\end{array}$ & \\
\hline & & $\begin{array}{l}\text { W. Whether a megaproject manager (especially for the top } \\
\text { manager) needs to have all competencies (technical, social, and } \\
\text { adaptive competencies) to achieve short-term and long-term } \\
\text { successful megaprojects? }\end{array}$ & \\
\hline 5. & $\begin{array}{l}\text { Contextual leadership } \\
\text { competency }\end{array}$ & $\begin{array}{l}\text { Whether the leadership competencies of megaproject managers } \\
\text { (especially top managers) need to be adjusted to the characteristics } \\
\text { of the megaproject (including its complexity)? }\end{array}$ & \\
\hline \multirow[t]{2}{*}{6.} & \multirow[t]{2}{*}{$\begin{array}{l}\text { Leadership competency training } \\
\text { \& sharing }\end{array}$} & $\begin{array}{l}\text { Is there any special training in your organization to } \\
\text { prepare candidates' competencies to become the main } \\
\text { megaproject manager (lead / top manager)? (please, explained). }\end{array}$ & \\
\hline & & $\begin{array}{l}\text { b. Is there a (regular) experience/knowledge-sharing activity } \\
\text { (especially the megaproject management) in your organization? }\end{array}$ & \\
\hline
\end{tabular}

Journal of Industrial Engineering and Management, 2021 (www.jiem.org)

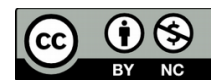

Article's contents are provided on an Attribution-Non Commercial 4.0 Creative commons International License. Readers are allowed to copy, distribute and communicate article's contents, provided the author's and Journal of Industrial Engineering and Management's names are included. It must not be used for commercial purposes. To see the complete license contents, please visit https://creativecommons.org/licenses/by-nc/4.0/. 